ÇOMÜ Uluslararası Sosyal Bilimler Dergisi 2(4), 117-150, 2017

COMU International Journal of Social Sciences 2(4), 117-150, 2017

\title{
Türk Resim Sanatında Renk Kullanımı
}

\author{
Güliz BAYDEMIR DABANLI*
}

\begin{abstract}
Öz
Türk minyatür sanatında biçime yaklaşım ve renge kısaca değinilerek, Türk resim sanatında akımlar, gruplar ve bireyler bağlamında renk; 19. yüzyıl ressamlarıIllk Türk ressamları, Çağdaş Türk resminin ilk dönemi - 1914 / Çallı Kuşağı, Müstakil Ressamlar ve Heykeltraşlar Birliği, D Grubu, Yeniler Grubu, Onlar Grubu ve Soyut Eğilimler sanatçıları ve resimlerinden örneklerle irdelenmiştir. Türk resim sanatında renk kullanımı gruplar bağlamında, bazı istisnalar olsa da genelde Batı sanatında renk kullanımının bir yansıması olarak görselleşmiş ancak bireysel özgünleşme arayışında olan sanatçılarda renk kullanımı daha deneysel ve özgür bir şekilde ortaya çıkmıştı. Yine de Türk resim sanatında yer alan eserlerde, genelleme yapılacak olursa, baskın bir şekilde yer almış olmakla birlikte renk; başı başına ana öğe ya da ana biçimsel yapı, formun maddesi ya da temel yapısı olarak belirgin bir şekilde işlev kazanmamıştır.
\end{abstract}

Anahtar Kelimeler: Renk, Resim, Türk Resmi, Sanat.

\section{Use of Colour in Turkish Painting}

\begin{abstract}
The study explains briefly the approach to form in the Turkish Miniature and the color, with examples from different groups and individuals of the Turkish art of painting, including $19^{\text {th }}$ Century Painters, First Turkish Painters, First Period of Contemporary Turkish Art - 1914 / Age of Çallı, Association of Individual Painters and Sculptors, Group D, New Painters Group, Group 10s.The use of colour in the Turkish Painting in terms of groups has been generally visualized as a reflection of use of colour in the Western Art, but the artists seeking individual authenticity have been and worked more experimental and free. Still, in works of arts of Turkish painting, even though the painters have generally used the colour in their paintings dominantly, the colour has never acquired a distinct function as the main element or main formal structure, or main structure or substance of form.
\end{abstract}

Keywords: Colour, Painting, Turkish Painting, Art.

* Arş. Gör., Çanakkale Onsekiz Mart Üniversitesi, Güzel Sanatlar Fakültesi Resim Bölümü, gulizbaydemir@ comu.edu.tr 


\section{GíRiş}

Croce'ye göre bir görüş ya da seziş olan sanatta, sanatçı bir imge ya da resim üretir. Yapıtın geliştirilmesi, kompozisyonu veya gerçekleştirilmesi biçimi yaratır. Resimsel elemanların, organizasyon ilkeleri uyarınca kullanımı ve düzenlenmesi ile ortaya çıkan biçim, yapıtın bütününü ifade eder. Bir yapıtın biçimselliği onun esası ana unsurudur. Sanatçının seçimleri, kullandığı biçimsel öğelerin hiyerarşisi nihai görünümü, biçimselliği belirleyerek sanat eserinin ifadesini ya da kavramını oluşturur. Bu biçimsellikten sonra seyirci için, içerik anlam kazanır.

Resim sanatının ana biçimsel öğeleri ya da yapı taşları nokta, çizgi, ton, renk ve dokudan oluşur. Bunlar sanatın tasarım elemanlarıdır. Bu biçimsel öğelerin biri, bir kaçı ya da hepsi kullanılarak biçimsel yapılar ya da formlar meydana getirilir. Bu biçimsel yapılar, sanatın tasarım ilkeleri olan temel kompozisyon ya da düzenleme ilkeleriyle armoni, denge, oran-orant, baskınlık, ritim/hareket, ekonomi, boş/dolu, büyük/küçük gibi prensiplerle oluşturulur. Renk, sanatın en önemli tasarım elemanlarından biridir.

Resimlerinde, içeriği veya biçimi vurgulamak için ressamlar çoğu kez renkten faydalanmışlardır. Fiziksel, psikofiziksel ve psikolojik bağlamlarda tanımlanan ve yüzyıllarca çeşitli biçimlerde sistematik olarak sınıflandırılmaya çalışılmış olan renk; görsel algı ile insanda uyandırdığı fizyolojik ve psikolojik etkilerden ve içerdiği anlam potansiyelinden ötürü resim sanatının vazgeçilemez biçimsel öğesi olarak, tarih boyunca görsel sanatların bütün dallarında süsleme, temsil ve anlatım amacıyla kullanılmıştır.

Renklere olan tutkularına göre ressamları iki gruba ayırmak eleştirmenler için büyük bir ilgi alanı olmuştur. Rengin ikinci sırada olduğu ve desenin işin ister başında olsun, ister sanatçının eğitimi sırasında olsun resimden önce geldiği öğretisi bu ayrımı yansıtmaktadır.

"Sanatçılar konularını, kavramlarını, hissiyatlarını ya da ifade etmek istediklerini Plastik / Resimsel yapılarla boyutlandırmaktadırlar: Bu yapıların en önemlilerinden birisi olan rengi zaman zaman bilinçli, zaman zaman da sezgisel olarak eserlerinde nesnelleştirmişlerdir. Rengi nesnelleştirirken çoğu zaman ifade etmek ya da oluşturmak istedikleri düşünceyi ya da hissiyat rengin değişik olanaklarını da kullanmak suretiyle ortaya koymuşlardır. Dönemsel ve bireysel kullanımında farklılıklar olmakla birlikte Resim Sanatında renk, genel olarak üç ana başlıkta işlevselleşmektedir.

1- Açık - koyu, ışı - gölge ve desen yapısındaki çalışmalarda yardıma öğe olarak işlevselleşmesi.

a) Rengin bir armoni ya da atmosfer etkisi elde etmek amaciyla daha çok tek renkli (monokrom) kullanımı.

b) Nesnelerde ya da figürlerde lokal tonun yanında lokal renk (nesnenin öz rengi) kullanımı.

c) Diğer renklerin ya da ışığın etkisiyle lokal rengin etkinliğinin azaldığı ya da yok olduğu kullanım. 
2- Farklı ton değerlerinin yer aldığı fakat rengin özelliklerinin ya da etkilerinin baskın bir şekilde işlevselleşmesi ya da kullanımı.

a) Rengin sistematik bir şekilde tuşlar ya da noktalar halinde tamamlayıcı renklerin yan yana kullanımıyla görsel algıda ya da gözde optik olarak oluştuğu kullanım

b) Hem ton değerleri hem renk olanaklarının dengeli bir şekilde doğanın izleniminin-atmosferinin görselleştirildiği kullanım

c) Rengin daha irticalen, sembolik, serbest ve bağımsı kullanımı

d) Rengin modleden bağımsız bir üç boyut yanılsaması oluşturma amacıyla modülasyon olarak kullanımı

3- Daha çok ton değerlerinin aynılaştı̆̆ı rengin başlı başına ana/baskın bir öğe, formun maddesi ve temel yapısı olarak işlevselleşmesi.

a) Orta ton değerleriyle rengin özünün baskın kullanımı.

b) Yakın ya da aynı ton değerleriyle doygunluğun baskın kullanımı."1

Batı resim sanatında renk uygulamalarının sistematik hale gelmesi, Rönesans'la beraber belirginleşir. Buna bağlı olarak renk kullanımı da önem kazanmaya başlar. 19. yüzyılın ortalarına kadar renk resimde çok önemli bir yer teşkil etse de yardımcı öğe olarak işlevselleşmiştir. 20. yüzyılda daha belirgin bir şekilde başat öğe ve yapı olarak resim sanatında yerini almıştır. Rönesans'tan sonra Maniyerizm'de rengin daha doygun kullanımıyla ifade artırımıştır. Barok dönemde ise renk ışık ile atmosfer etkisi elde etmek için monokrom olarak kullanılmış; ayrıca, diğer renklerin ve ışığın etkisiyle lokal renk etkisi azalmıştır. Romantik sanatçılar özellikle de Delacroix, üç boyut yanılsaması elde etmek için planları/yüzeyleri zıt ya da tamamlayıcı renklerle ayırt etmekle birlikte bir rengin farklı renk ve ton olanaklarından da yararlanmıştı. Saf renkleri tuşlar halinde sürerek renk karışımını seyircinin gözünde oluşturmayı amaçlayan ve renk parçalarından oluşan yeni bir form anlayışı oluşturan Empresyonistler, rengin çok farklı ve çeşitli olanaklarını kullanarak sonraki dönemlere, akımlara ve sanatçılara belirgin bir şekilde etki etmişlerdir. Post-Empresyonizmin temsilcisi Van Gogh, rengi daha serbest, özgür ve irticalen kullanarak Ekspresyonist sanatçıların renk kullanımını etkilemiştir. Gauguin'in rengi hem sembolik hem de renk alanlarını vurgulu olarak kullanı$\mathrm{m}$ soyut geometrik ve lirik yaklaşımlara (özellikle de Matisse, Vlamink, Derain, Doesbourg ve Mondrian gibi) önemli etkileri olmuştur. Cezanne'ın ise üç boyut yanılsaması oluşturmak amacıyla rengin zıtlık ve tamamlayıcı özellikleriyle modülasyona başvurması, sonraki dönemlerdeki tüm sanatçılara üç boyut yanılsaması elde etme bağlamında yenilikler getirmiştir. Yine Neo-Empresyonistlerin bilimsel olarak seçtikleri karşıt renklerin palette karıştırılmadan saf renkler olarak küçük firça vuruşlarıyla tuval üstünde yan yana uygulanmasını kurallandırmış oldukları Noktacılık ve Bölmecilik gibi yöntemler tüm modern sürecin renk kullanımını derinden etkilemiştir (Orfizm, Fütürizm, vb). Dolayısıyla, genelde Empresyonizm ve bu akımdaki sanatçılar bugüne kadar resim sanatında renk kullanımının en önem-

1 M. O. Müftüoğlu, “Renk Üzerine Söyleşi”, İstanbul, MSGSÜ, 2016. 
li mihenk taşları olmuşlardır. Empresyonistler sonraki dönemlere renk kullanımı bağlamında geniş olanakların olduğunu göstermiş ve onları derinden etkileyerek modernizmin renk algısının temellerini oluşturmuşlardır. Ton değerlerinin görece olarak aynılaştırılmasıyla yani ton kontrastlıklarının azaltılmasıyla, ana öğe ya da yapı olarak renk, başlı başına resmin varlık sebebi olmaya başlamış ve temelde renk özünün ve doygunluğunun baskın kullanımı ortaya çıkmıştır.

Türk resim sanatında ise; yüzyıllar boyunca tek egemen güç olan Türk minyatür sanatından sonra, batılılaşma hareketlerinin yaşanması ve doğayı bilimsel yöntemle tanımayı öngören gerçekçiliğin, ışık-gölge denemeleri ile Bat üslubunda yağlıboya resim tekniğinin uygulanmaya başlandığı dönemden itibaren çok hızlı bir şekilde kat ettiği yolda, rengin kullanım olanakları ve biçimleri incelenmeye açıktır.

Türk resim sanatında rengin sanatçıların yapıtlarında biçimsel olarak nasıl işlevselleştiği, baskın bir şekilde yer alıp almadığı, başlı başına ana öğe ya da ana biçimsel yapı, formun maddesi ya da temel yapısı olarak belirgin bir şekilde işlev kazanıp kazanmadığı hususunda saptamalara varmak, bu çalışmanın amacını oluşturmaktadır. Türk resminde renk kullanımı ile ilgili çok kısıtlı kaynak bulunmakla birlikte, Mimar Sinan Güzel Sanatlar Üniversitesi Güzel Sanatlar Enstitüsü Resim Anasanat Dalı Resim Programı́nda hazırlamış olduğum "Türk Resim Sanatında Renk Kullanımı" başlıklı Sanatta Yeterlik Eser Metninden türetmiş olduğum bu makalede; ilgili söyleşi, kitap, ansiklopedi, makale, katalog ve tez çalışmaları veri sağlayan kaynaklardır.

\section{MINYATÜR SANATINDA BIÇIME YAKLAŞIM VE RENK}

Resim sanat Bat'da tuval resmi olarak uygulanırken, İslam sanatında kitap sayfalarında yer almıştır. "El yazması kitapları süslemek ve konuları daha iyi açıklayabilmek için yapılmış olan minyatür, yüzyıllar boyunca Türk resim sanatının tek egemen gücü olmuştur. Uygurlarda Mani dini içerisinde şekillenen, Türk minyatürü daha sonra İslam dini çerçevesinde eserler vermeye başlamıştır." ${ }^{2}$ Minyatürde üçüncü boyuttan mümkün olduğunca kaçınılmıştır. Katışıksız renk lekelerine ve belirgin kontürlere dayanan gölgesiz, yüzeysel bir tekniğe dayanır. Batılı sanatçılar minyatürün özelliklerinden ve renklerinden faydalanmışlardır. Özellikle kırmızı, mor ve turuncunun diğer renklere oranla üstünlük sağladığı Türk minyatürlerinde kullanılmış olan kırmızı; Bat dünyasında "Türk kırmızısı" adı ile adlandırılmış olup, dünyanın hayranlığını kazanmıştır.

2 M. Boran, Türk Minyatür Sanatında Renk (Yüksek Lisans Tezi), Van, Yüzüncü Yıl Üniversitesi / Sosyal Bilimler Enstitüsü / Güzel Sanatlar Eğitimi Anabilim Dalı /Resim - İş Eğitimi Bilim Dalı, 2000, s. V. 
Resim 1. Levni, Sultan III. Ahmet, Kebir Musavver Silsilename, 1710-20, Minyatür, Topkapı Sarayı Müzesi.

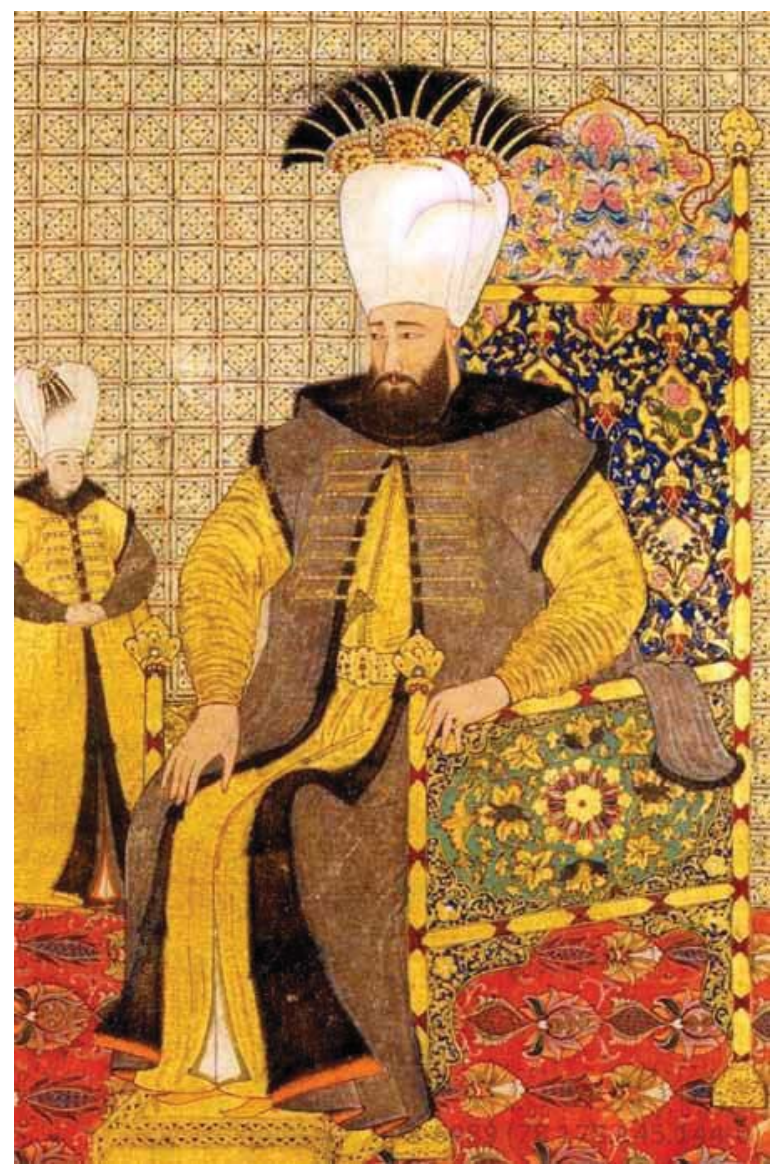

Kaynak: S. Bağcı, F, Çağman, G. Renda, Z. Tanındı, Osmanlı Resim Sanat,, Ankara, T.C. Kültür ve Turizm Bakanlığı Yayınları, 2012, s.262.

Minyatür sanatçıları eserlerinde imza yerine ayırt edilebilir olarak üsluplarını yansıtırken konu, çizgi, kompozisyon ve renk özelliklerini ortaya koymuşlardır. Minyatürde büyük ölçüde konu ön plandadır. Konu, çizgi ve kompozisyon belirli sınırlar içinde kalırken renk, bu sınırların dışına taşan en önemli özellik olmuştur. " "Minyatür sanatçısı rengi kullanmada son derece özgür davranmıştır. Mesela atların yeşile, eflatuna, pembeye boyanması, tepelerin kırmızı renkle ifade edilmesi, bunun en önemli göstergesidir." ${ }^{4}$

Minyatür sanatında çizgi ile yarışan ve lekesel olarak kullanılan renk, zaman zaman biçimleri daha etkili kılmak ve bir hiyerarşi yaratmak için önem kazanmış ve başı başına bir görev yüklenmeden bir çeşit nakışı tamamlayan boyamadan, bir süsleme renkçiliğinden güç alarak, doğa ile kullanılan şematik bir ilişkiyi yansıtmaktadır. Zaman zaman hayalci bir renk tutumu görülse de genellikle nesne ya da figürlerin kendi öz renkleri lokallikleri dikkate alınarak betimlemeler oluşturulmuş, ayrıca rengin sembolik etkileri de vurgulanmıştır.

3 A.g.e., s. V.

4 A.g.e., s. V. 


\section{TÜRK RESIM SANATINDA RENK}

Osmanlı'da Batı'ya açılma hareketinin aşırı batılılaşmaya dönüştüğü Batı'dan İstanbul'a gelen pek çok yağlıboya ressamının perspektifli duvar resimleri, manzaraları ile tanışılan Tanzimat döneminde Şeker Ahmet Paşa, Hüseyin Zekai Paşa gibi manzara ressamlarının yetişerek Türk resminin geleneksel biçimlerden uzaklaşması önemli bir geçiş dönemidir. "Türk resminde ciddi Batılılaşma hareketi, doğayı bilimsel (gözlemci) yöntemle tanımayı öngören gerçekçiliğin Batı üslubunda yağlıboya resimde denenmesi ile başlar." ${ }^{5}$ Figür resminde 18 . yüzyıl minyatürüne giren Levni'nin büyük figürlü bir iki çalışmasında görülen, ışık-gölge denemeleri, bilimsel açıdan gerçekçi figür araştırmasına bir başlangıç olarak kabul edilemezken; Osman Hamdi'nin figür çalışmaları, dramatik niteliğe sahip olmayan, aralarında organik ilişkiler yaratılamamış figürler olsalar da, Türk resminde radikal bir atılımdır. ${ }^{6}$

Resim 2. Ali Cemal, Sarıkı ihtiyar, 1906, Tuval Üzerine Yağlıboya, 40.5x32cm, İstanbul Resim Heykel Müzesi.

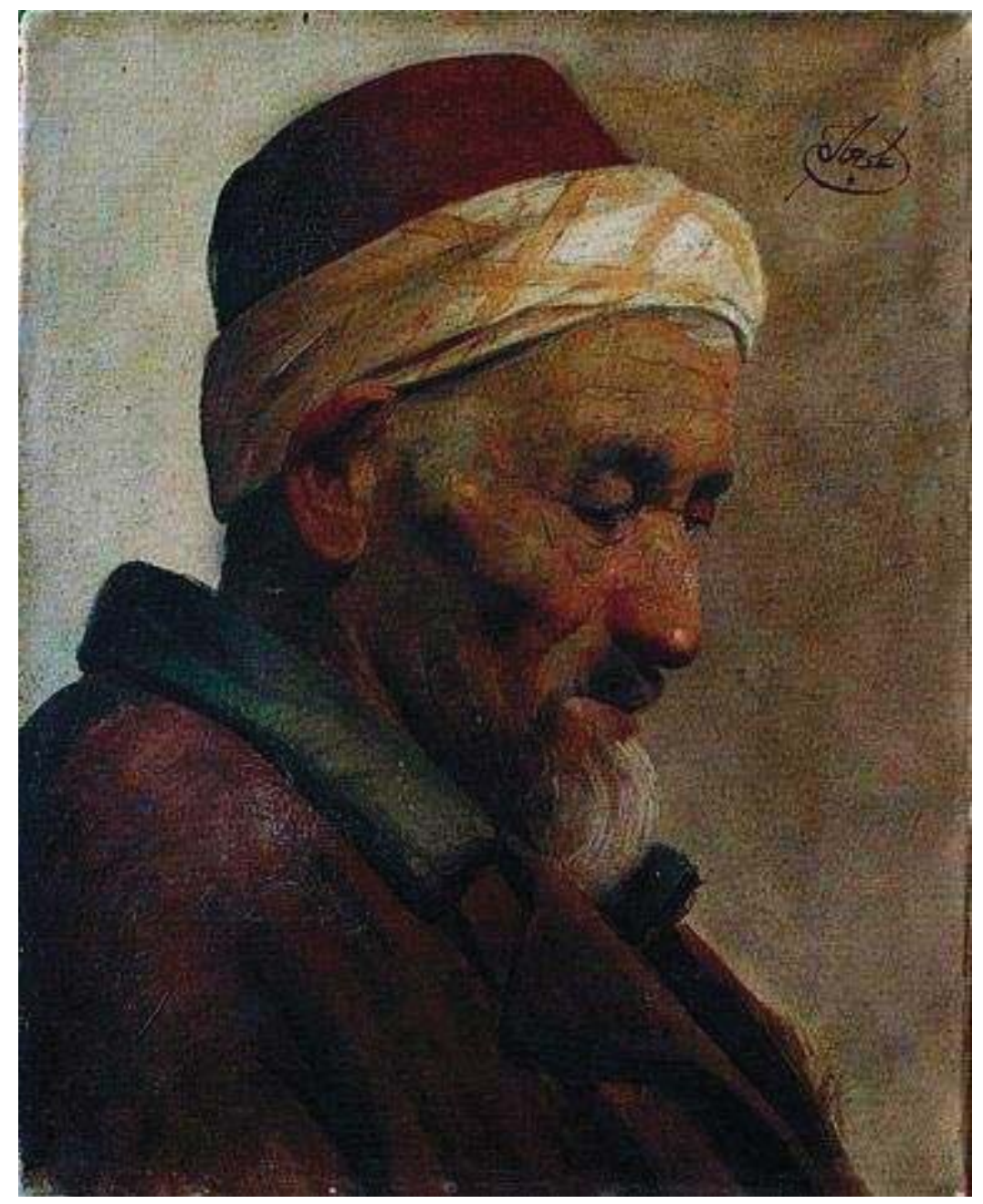

Kaynak: I. Duben, Türk Resmi ve Eleștirisi, İstanbul, Bilgi Üniversitesi Yayınları, 2007, s. 76.

5 i. Duben, Türk Resmi ve Eleştirisi, İstanbul, Bilgi Üniversitesi Yayınları, 2007, s. 29.

6 A.g.e., s. 74. 
Osman Hamdi, Muallim Şevket, Ahmet Ziya Akbulut ve Şevket Dağ'ın resimlerinde çizgisel perspektifin gelişimi izlenir. İsmail Hakkı Altınbezer, Tekezade Sait, Ali Cemal, Sami Yetik, Nazmi Ziya Güran, İzzet Bey, Mehmet Ruhi, İbrahim Çallı ve Hikmet Onat gibi Sanayi-i Nefise Mektebi öğrencileri Salvator Valeri, Warnia Zarzecki ve Yervant Oskan'ın natüralist akademik eğitiminden geçmişlerdir. ${ }^{7}$

Figür ve portreyi ön planda, sınırları keskin ve kapalı bir form oluşturacak biçimde ele alıp, tüm ayrıntıları ile natüralist bir üslupta işlemiş olan ilk figür ressamları; ton, çizgi, madde ve perspektif bilgilerini kullanarak, beyaz kağıt üzerinde figüre hacim vermek amacını güderken rengi de ulaşmak istedikleri natüralist etkiyi yaratmada bir araç olarak kullanmışlardır. Fotografik natüralist üslup, Güzel Sanatlar Birliği sergilerinde de varlığını sürdürmeye devam etmiştir. Duben, ilk kuşak ressamların Osman Hamdi'nin temsil ettiği üslubu bilinçli veya bilinçsiz klasik olarak görmüş ve o çizgiyi izlemiş olduklarını söyler. "Ressam Saip, Ayetullah Sümer, Mahmut Cuda gibi daha sonra gelen ressamların, değişen kültürel çevreye rağmen bu üsluba körü körüne bağıı kalmaları onları akademik yapmıştır." ${ }^{8} \mathrm{Bu}$ dönemde figüre yönelip Bat örneklerini taklit ederek; biçimsel öğeleri ve kurguyu olduğu gibi Batı'dan almış olan sanatçıların resimlerinde renk yardımcı öğe olarak işlevselleşmiştir. "Önceleri fotoğraftan yararlanarak doğayı taklit etmeye çalışan ressamlar, 1910'lardan sonra izlenimciliğe gireceklerdir." ${ }^{\prime 2} 1910$ 'larda Avrupa'ya eğitime gönderilen İbrahim Çallı, Hikmet Onat, Ruhi, Sami Bey ve Nazmi Ziya Güran, 1913-1914 yıllarında empresyonizmden etkilenmiş olarak yurda döneceklerdir.

\subsection{Yüzyıl Ressamları- İlk Türk Ressamları}

Batı anlayışına dönük Türk resim sanat 19. yüzyılın ilk yarısından itibaren, Mühendishane-i Berri Humayun ve Mekteb-i Harbiye gibi askeri okulların askeri ve teknik alanda başlatth̆̆ yenileşme hareketleriyle temellenmiş olup 19. yüzyıl ilk Türk ressamlarının çoğu askeri okul çıkışlıdır. "Bu ressamlar Bat anlayışına dönük ortak bir manzara ve natürmort üslubunda eserler vermişlerdir." 10

Asker ressamlar kuşağının çok önemli bir üyesi olan Hoca Ali Rıza, Türk resim sanatının önemli bir manzara ressamıdır. Nurullah Berk, Hoca Ali Rıza'nın, doğayı göremeyenlere doğayı yakınlaştırdığını söyler. ${ }^{11}$ "Doğaya kendi deneyimli gözleri ile bakan Hoca Ali Rıza, gördüğünü, perspektifle, renkle, ışık-gölgeyle, eş deyişle, sanata özgü elemanlarla hoş kılar. İzleyicinin hiç göremeyeceği veya doğal haliyle ona (izleyiciye) belki de güzel gelmeyecek bu ıssız ve vahşi köşeyi estetik beğeniye uygun hale dönüştürür." ${ }^{\prime 2}$

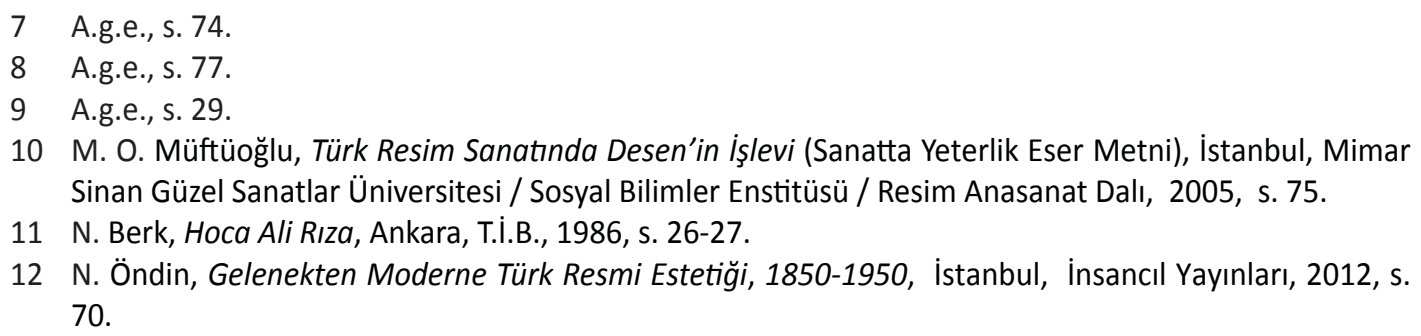

12 N. Öndin, Gelenekten Moderne Türk Resmi Estetiği, 1850-1950, İstanbul, İnsancıl Yayınları, 2012, s. 70. 
Resim 3. Hoca Ali Rıza, Peyzaj, 1922, Kağıt Üzerine Guaş, 20 x 27 cm, Özel Koleksiyon.

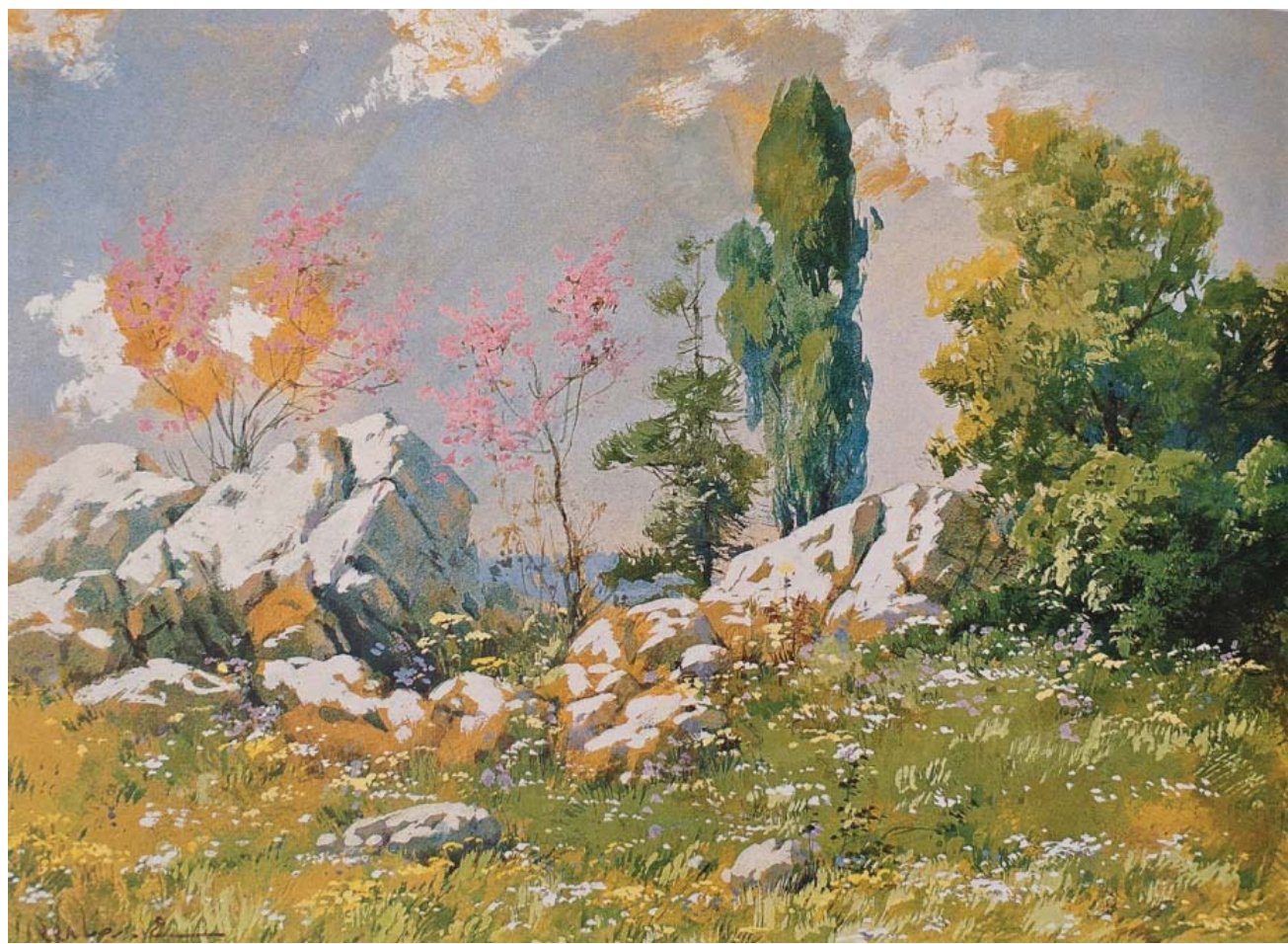

Kaynak: Ö. F. Şerifoğlu, Hoca Ali Rıza 1858-1930, İstanbul, Yapı Kredi Yayınları, 2005, s.56.

Resmi sokakta yapmayı ve doğayı açık havada izlemeyi öğretmesi, Hoca Ali Rıza'nın Türk resmine en büyük katkısıdır. Halil Paşa ile birlikte Türkiye'de empresyonizme öncülük ettikleri söylenebilir. Osman Hamdi ve Ömer Adil gibi ışığı boşlukta hareketlendirebilen birkaç Türk sanatçısı dışında, Sanayi-i Nefise'de yetişen ressamlar 1940'lara kadar figürü modülasyonla hacimlendirirken, Hoca Ali Rıza ışığı resmin yüzeyinde dağıtmaya çalışmış, temiz ve parlak renkler kullanmıştır. ${ }^{13}$ Çallı Kuşağı'na geçiş oluşturan Hoca Ali Rıza ve Halil Paşa gibi ressamlar hem ton hem de izlenim etkileri elde etmiş, renk onlar için bütünlük sağlayıcı unsur olmuştur.

İnsanı ve nesneyi keşfetme yolunda Rönesans'ın perspektifli mekân kurgusunu ve dramatik figür yorumunu ele almış olan Osman Hamdi, Halil Paşa ve Abdülmecit gibi ressamlar Batı'yı biçimsel olarak taklit etmişlerdir, fakat geleneksel zihniyetin etkileri mekân kurgusunda iki boyut/ üç boyut çelişkisi olarak tekrar tekrar görülmüştür. ${ }^{14}$

Öndin; Klasik estetikte, güzelliğin harmonik formda olmasının rengi ikincil konuma atthğını, rengin formun etkisi ve derecesini yükseltmek için güzelliğe yardımcı olduğunu ancak tek başına güzelliği yaratamayacağını; form güzel olunca rengin de güzel olarak idrak edildiğini söyler. ${ }^{15}$ "Osman Hamdi Bey de gerçekçi anlayışla formu ve rengi değerlendirirken, nesnenin yapısını, özeliklerini bozmaz, tüm ayrıntılarını işler, bütünün parçalanmamasına özen gösterir. Renkte, nesnenin kendi

13 i. Duben, Türk Resmi ve Eleştirisi, İstanbul, Bilgi Üniversitesi Yayınları, 2007, s. 142.

14 A.g.e., s. 92.

15 N. Öndin, Gelenekten Moderne Türk Resmi Estetiği 1850-1950, İstanbul, İnsancıl Yayınları, 2011, s.87. 
rengine hep bağlı kalır." 16 Türk resminin ilk ve en önemli figüratif çalışmalarını üreten Osman Hamdi Bey, rengi çok kontrollü ve tasarruflu kullanmış, biçime forma önem vermiştir. Aynı zamanda lokal renk onun resimlerinde vazgeçilmezdir.

\section{Resim 4. Osman Hamdi Bey, Ab-ı Hayat Çeşmesi, 1904, Tuval Üzerine Yağlıboya, $200 \times 151 \mathrm{~cm}$, Alte und Neue National Galerie Berlin.}

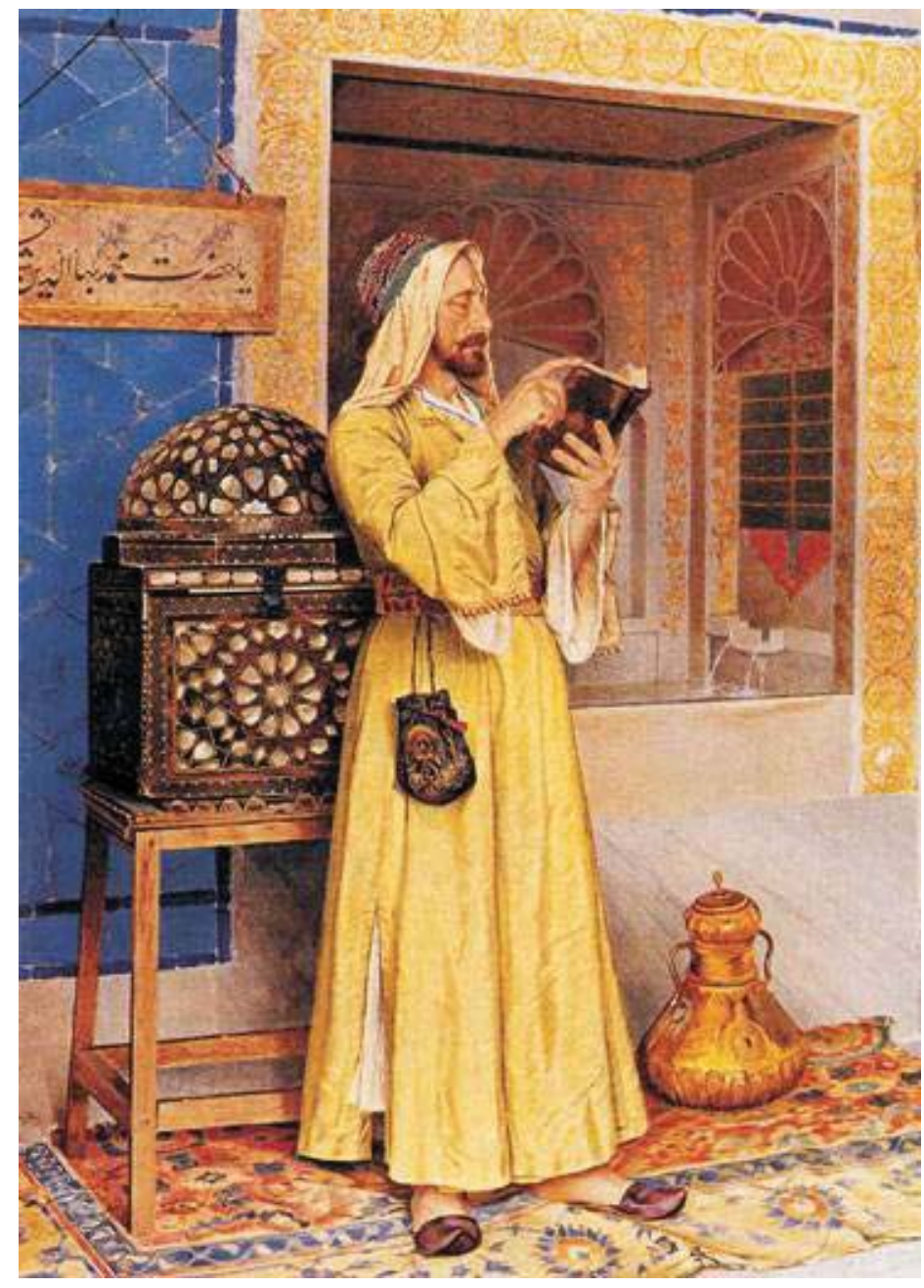

Kaynak: E. Eldem, Osman Hamdi Bey Sözlügü,. Ankara, T.C. Kültür ve Turizm Bakanlığı Yayınları, 2010, s. 24.

Şeker Ahmet Paşa, 'Ormanın Sükuneti' (1906) adlı yapıtında, ışık ve renk kullanımı ile biçimlerin sertliğini, direncini kendi iç görüşünde eriterek, dirençsiz-yumuşakIığın karşılığı olan sükuneti görselleştirdiği gibi, resmine ad olarak da vermiştir. ${ }^{17}$ "Sükunet dengenin karşılığı olarak ele alınırsa, resmin dengesi de renk ile ışık bütünleşmesi olarak sükunet içindedir. Göz dengeli dinginlikte sanki usul usul dolaşır. Burada renklerin tonları kadar renk birlikteliğinden oluşan uyum ile kendisi uyum olan kâinat eserinde görünüş olarak ortaya koyar." ${ }^{18}$ Şeker Ahmet Paşa'nın

16 R. Epikman, Osman Hamdi, İstanbul, MEB, 1967, s. 3.

17 N. Öndin, Gelenekten Moderne Türk Resmi Estetiği 1850-1950, İstanbul, İnsancıl Yayınları, 2011, s.59.

18 A.g.e., 59. 
çalışmalarında renk, Osman Hamdi Bey'in renk kullanımıyla paralellik gösterse de esas olarak lokal rengin etkinliği azalmakta, monokrom (tek renklilik) etkilerin yoğun bir şekilde kullanımı gözlenmektedir.

Resim 5. Şeker Ahmet Paşa, Ormanın Sükuneti, 1906, Tuval Üzerine Yağılıboya, 130x88,5cm, MSGSÜ İstanbul Resim Heykel Müzesi

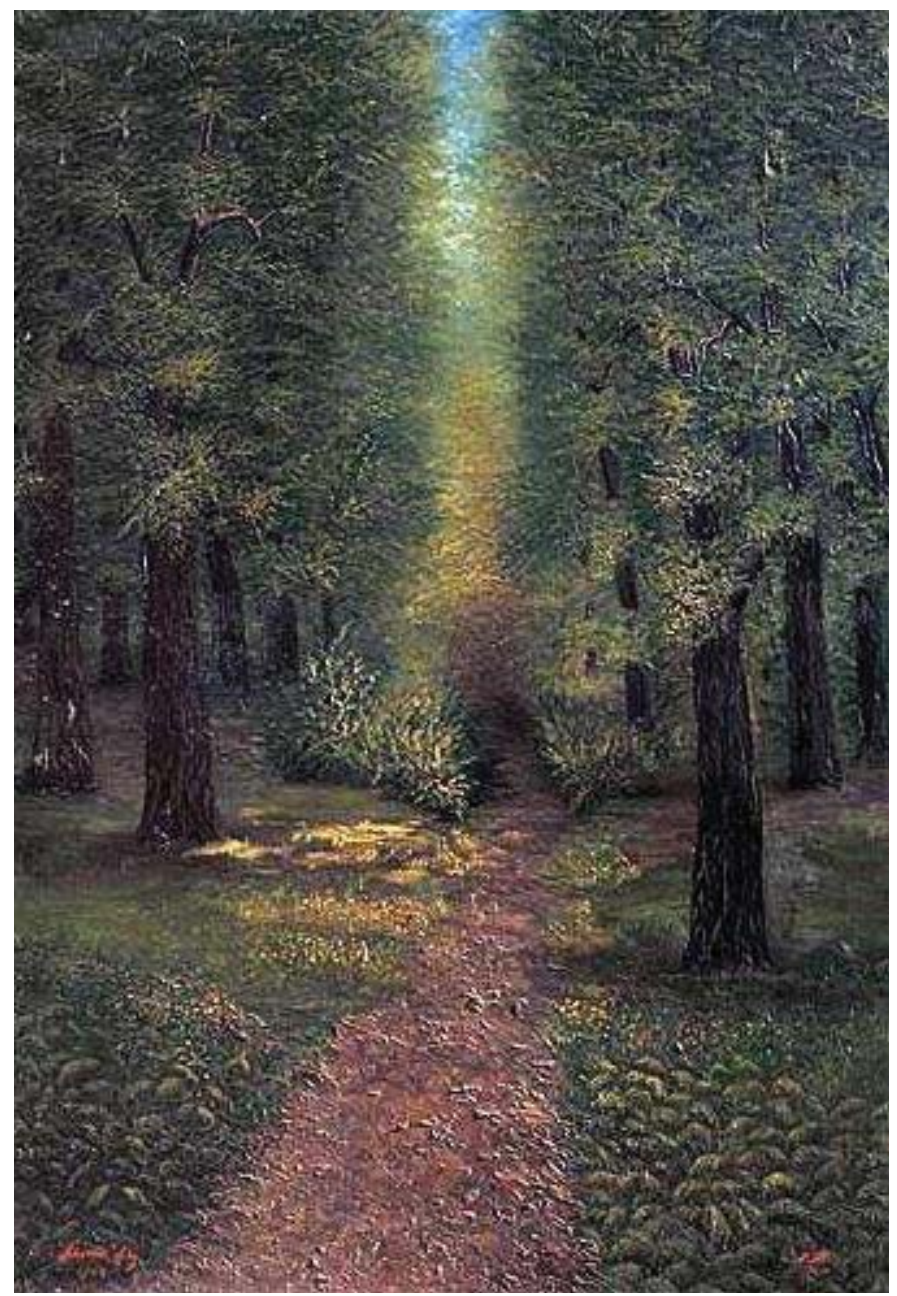

Kaynak: N. Öndin, Gelenekten Moderne Türk Resmi Estetiği 1850-1950, İstanbul, Insancıl Yayınları, 2012, Kapak.

Illk Türk ressamlarının, özellikle fotoğraf kullanmaları ve betimlemeci bir yaklaşımla eserler vermeleri renk kullanımlarını da bu bağlamda etkilemiştir. Gölge gibi biçimsel yapıların yanında renk, yardımcı öğe olarak zaman zaman lokal değerler zaman zaman da bir armoni ya da atmosfer bütünlüğü yaratmak amacıyla kullanılmıştır.

\section{2. Çağdaş Türk Resminin illk Dönemi - 1914 / Çallı Kuşağı (Türk İzlenimcileri / Empresyonistleri)}

Sanayi-i Nefise Mektebi'nden mezun olduktan sonra 1910'da devlet bursuyla Avrupa'nın çeşitli ülkelerinde sanat eğitimi gören ve 1914 'te Birinci Dünya Savaşı'nın başlamasıyla geri dönerek Türk Resim Sanatında yeni bir dönemi başlatan sanatçı topluluğu, 1914 Kuşağı olarak adlandırılır. Renkli sanatçı kişiliği, sanat 
çevresindeki etkin konumu nedeniyle grubun önderi olarak anılan İbrahim Çallı ile Mehmet Sami Yetik, Nazmi Ziya Güran, Hüseyin Avni Lifij, Feyhaman Duran, Namık İsmail, Mehmet Ruhi (Arel), Hikmet Onat ve Ali Sami Boyar'dan oluşur. Yenilikçi görüşlerin yaygınlaşmasında önemli rol oynayan "Galatasaray Sergileri" adıyla anılan sergiler düzenlemişler, yarattıkları sanat ortamıyla çağdaş Türk sanatının oluşumunu etkilemişlerdir. "1914 Kuşağı, ilk Galatasaray Sergisi'ndeki manzara ağırlıklı resimlerinde Batı'dan aldıkları parlak gün ışığı ve açık tonda saf renkler kullandıklarından ötürü sanat çevrelerinde İzlenimciler diye adlandırılmışlardır (İzlenimcilik)." ${ }^{19}$ Dinamik ve ritmik bir ifade ile figür, manzara, ölüdoğa temalarına farklı yorumlar katarak klasik resmin durağanlığına tezat bir tutum sergilemişlerdir. Açık havada, değişken gün ışığının nesneler üzerindeki renk etkilerini araştıran sanatçılar, ayrıca çıplak modelle de çalışma olanağı bulmuşlardır. Sami Yetik, Mehmet Ali Laga, ibrahim Çallı, Ali Cemal, Namık İsmail, Hikmet Onat ve Sami Yetik ise I. Dünya Savaşı sırasında 1917'de kurulan Şişli Atölyesi'nde epik, dinamik ve lirik temalar içeren birçok savaş resmi yapmışlardır. Harbiye Nazırı Enver Paşa'nın emriyle kurulan bu atölyede, savaş araçları ve poz veren askerler kullanılmıştır.

Resim 6. Hüseyin Avni Lifij, Mezarlık, 1986-1927, Kontralit Üzerine Yağlıboya, $58 \times 47 \mathrm{~cm}$, Prof. Şazi Sirel-Ayten Sirel Koleksiyonu.

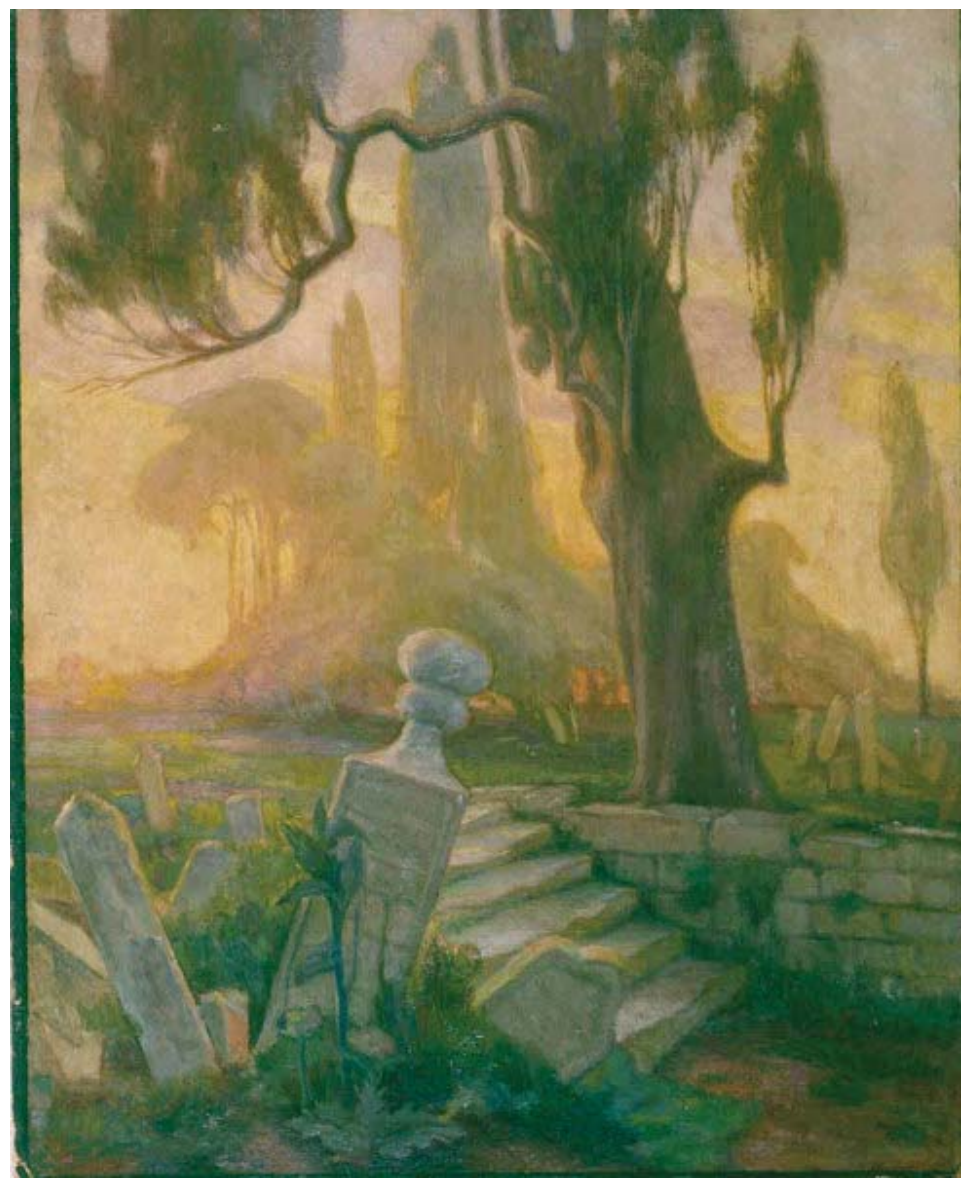

Kaynak: A. K. Gören., Avni Lifij, İstanbul, Yapı Kredi Yayınları, 2001, s. 320.

19 E. Şahin, "1914 Kuşağı”, Eczacıbaşı Sanat Ansiklopedisi, İstanbul, Yapı-Endüstri Merkezi Yayınları, 1997, s. 245. 
Dönemin sanatçılarından Avni Lifij'in resimlerinde ve poşatlarında renk, bütünlük, armoni ve atmosfer etkisini güçlendiren bir unsur olmasının yanında yaşam ve ölüm temaları ile ebedi bir anlamı vurgulayan sembolik anlamlar da taşımaktadır.

\begin{abstract}
"Dış dünyaya ait verili olan, sanatçının içsel görüsüne dönüştürüldügü oranda, bireysel gerçekliğe işaret eder. Hüzünlü bir şiirin atmosferiyle kaplı doğa betimlemeleriyle Hüseyin Avni Lifij de, doğanın ötesinde kalan anlamı düşündürtür izleyicisine. Mezarlıklar, serviler, batmakta olan güneş, ıssız mekânlar ile oluşturduğu yalnızlık duygusu yaşam-ölüm ikilemine işaret ederken, durağan atmosferlerle de zamansızlık vurgulanır. Hüseyin Avni Lifij'in 'Mezarlık' adlı yapıtı da yaşam-ölüm ikilemini, gerçekliğin arkasında kalan anlamı, gizemi vurgular. Mezarlar, insan yaşamının sonluluğuna bir göndermedir. Yaşam sonludur, evren ise sonsuz ve sürekli. Bu bağlamda mezarlıklar, evrenin sonsuzluğunu, sonlulukta ortaya koyar. Yalnızlık duygusunun kızıl-sarı renk kullanımı ile vurgulandığı yapıtta, her şey sanki silüet görüntülere dönüşmektedir. İzleyici ilk anda nesne yokluğu yaşarken, zamanla kızıl renk ve tonları arasındaki silüet görüntülere dönüşmektedir. Rengin forma olan başatlığı, izleyicinin resmi kendi imgelemiyle tamamlamasına olanak tanırken, yapıta şiirsellik katar."20
\end{abstract}

Lifij, bir Post-Empresyonist sanatçı gibi nesnelerin lokal renklerini, renk ışık yöntemine göre koruduğu ve koyuluk-açıklık kontrastlarının ışıksal ve renksel amaçlarla aza indirgendiği poşadlarında ise serbest bir üslup kullanmıştır. ${ }^{21}$ Atmosferik bir etkiye sahip bu poşadlarda sıcak-soğuk zıtlığını grileri çok zengin bir şekilde kullanarak yaratmıştır.

Dönemin bir diğer sanatçısı Hikmet Onat, resimlerinde renk ile doğadaki ışıklılık etkisini vurgulamıştır. "Ağaçlar Altında Dikiş Diken Kadın'ında, ön planda yerde oturan figür, geleneksel kontur çizgisi yerine, Türk empresyonistlerinde tipik olarak görülmeye başlayan, renk kümelerinin kapalı bir form oluşturarak figürü çevresinden koparışını örnekler."22

20 N. Öndin, Gelenekten Moderne Türk Resmi Estetiği 1850-1950, İstanbul, İnsancıl Yayınları, 2011, s.104.

21 A. Çoker, "Avni Lifij'in Sanat", Avni Lifij Poşadlar, İstanbul, Aksoy Grafik, 1984, s.XXVII.

22 i. Duben, Türk Resmi ve Eleştirisi, İstanbul, Bilgi Üniversitesi Yayınları, 2007, s. 86. 
Resim 7. Namık İsmail, Harman, 1923 Tuval Üzerine Yağlıboya, $165 \times 200 \mathrm{~cm}$, MSGSÜ İstanbul Resim Heykel Müzesi

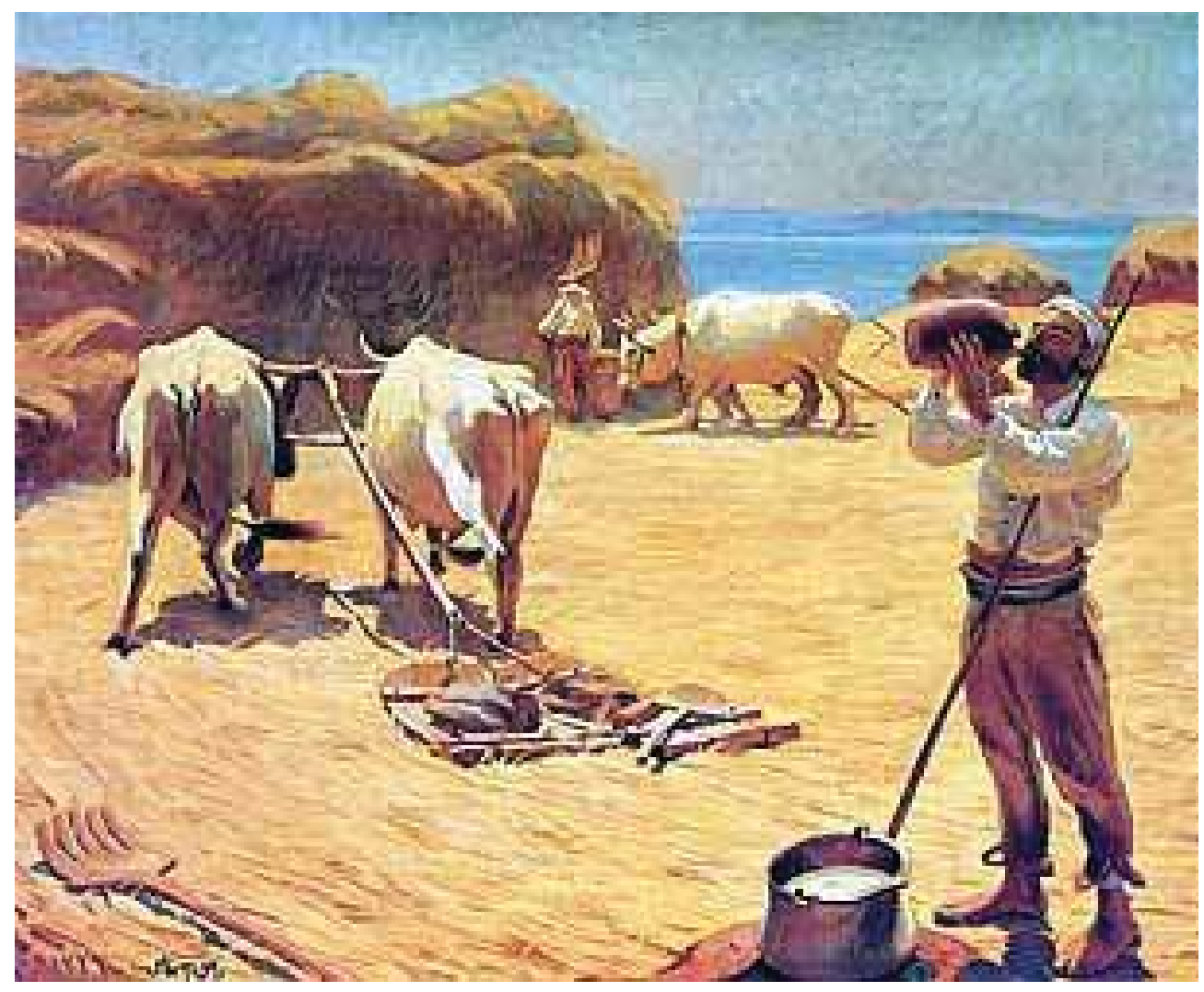

Kaynak: Z. Rona, Namık Issmail, Yapı Kredi Yayınları, İstanbul, 1992, s. 117.

Bu yıllarda ilginç eserler veren bir sanatçı da Namık İsmail'dir. Çok sayıda figür ve portre resmi yapmıştır. Resimlerinde en belirgin özellik ışığın ana tema üzerinde toplanmasıdır. Dışavurumcu ve lekeci bir tavırla formun her yanını aydınlatarak ışığın etkisini yakalamaya çalışmıştır. Duben, Namık İsmail'in renk kullanımı hakkında; "Doğanın ışığını inceleyen Batı empresyonistlerinin amacı, duyular yoluyla, deneye dayanan bilimsel bir ışık sistemini renklerle kullanmakt. Oysa Namık İsmail, rengi kendi ruhunun denklemi olarak kullandı....Namık İsmail'in ışıkla yarattığı tinsel dünya, onu bir ölçüde Van Gogh, Rouault gibi sanatçılara da yaklaştırır."23 saptamasında bulunur. Fransız Empresyonistleri ile Türk Empresyonistlerini ise şu şekilde karşılaştırır:

“1870-1880 yıllarında doruğa ulaşan empresyonizm, büyük Bat geleneğine karşı güçlü bir tepkiydi ve etkisi modern sanatın her alanında hissedildi. Bu akımın öncüleri Renoir, Monet ve Pisarro gerçekçi ressamlardı. Amaçları, sürekli hareket eden ışığın su üstüne yansımasını resmetmekti. Suda dalgalanan ışığın, koyu tonlar kullanmadan, saf renklerin karşıtlığı ile görüntülenebileceğini düşünüyorlardı. Böylece, renk kuramına aldırmaksızın ışık, hareket ve hacim yaratmaya koyuldular. İmgeyi chiaroscuro ve soyut form kullanmadan, sadece ışık yansıması olarak biçimlendirdiler. Doğayı

23 A.g.e., s. 87. 
tek bir elemanla, yalnızca ışıkla yorumladılar. Sonuç olarak, ışık gerçekliğin parçası olmaktan çıkarak bir üslup ilkesine dönüştü ve empresyonizm doğdu. Empresyonistler gerçekliği, duyusal algılamayı notlayarak saptamaya çalıştlar. Örneğin, Saman Yığını serisinde Monet aynı manzaranın saatlerine göre değişen ışığının retinadaki etkilerini izlemiştir." 24

Duben, Ibrahim Çallı ve Namık İsmail gibi Türk empresyonistlerinin ise Türk resmine biçimsel bir yenilik getirmediklerini fakat özgün bir renk ve ışık anlayışı yaratmış olduklarını vurgular. ${ }^{25}$ "Çallı'nın parlak renkleri, yüz ve vücut ifadelerindeki tedirginlik, çekingenlik; Namık İsmail'de aynı tedirginlik ve çok özel ışık kullanımı, Türk resminin özgün çözümleme arayışı içinde saygın aşamalar olarak görülebilir." 26

İbrahim Çallı, Feyhaman Duran, Namık İsmail, Avni Lifij gibi sanatçılar, akademik etkide olan bir empresyonizmi tercih etmişler, zaman zaman modle ve çoğu zaman da modülasyon etkisini kullanmışlardır. Atak ve aceleci firça vuruşlarındaki güçlü tekniği ve ustalığı ile diğer sanatçılardan ayrılan Çallı'nın formlardaki uyumu da göz ardı edilemez. Kendine has bir izlenimcilik anlayışıyla ışık-gölge tekniğine dayanarak konstrüktif eserler meydana getirmiştir.

Resim 8. İbrahim Çallı, Adada Gezinti, 70x100cm, Tuval Üzerine Yağlıboya, Özel Koleksiyon

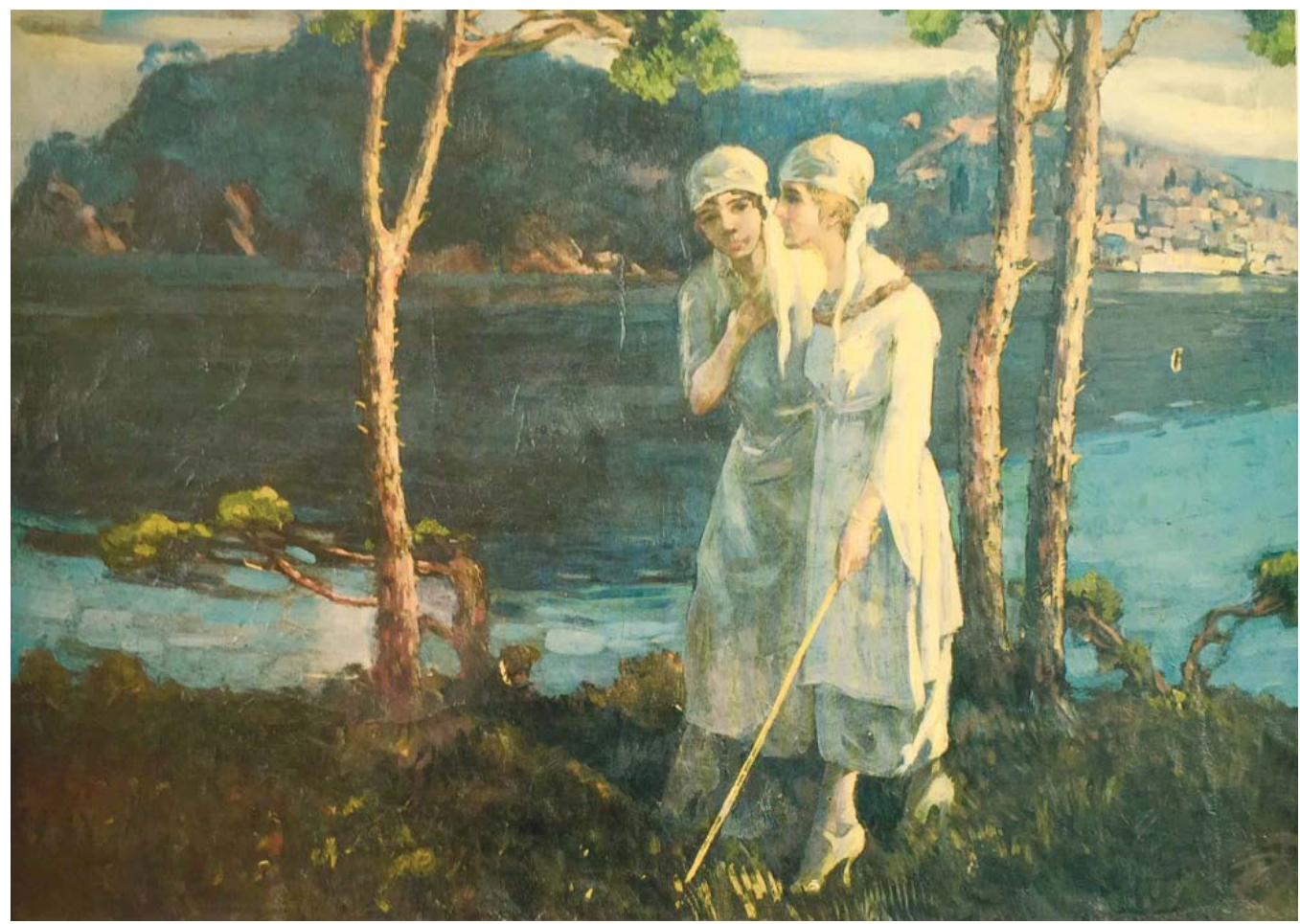

Kaynak: K. Özsezgin., Ibrahim Çallı, İstanbul, Yapı Kredi Yayınları, 1993, s.138.

\footnotetext{
24 A.g.e., s. 147.

25 A.g.e., s. 88.

26 A.g.e., s. 88.
} 
Bir diğer 1914 Kuşağı sanatçısı olan Nazmi Ziya'nın resimlerinden, Bedri Rahmi Eyüboğlu şöyle bahseder:

"Fakat güneş Nazmi Ziya'nın resimlerinde eşyanın rengini ve formunu eriterek bütün motiflerin üzerine sıcak bir buğu halinde çöker. (...) Nazmi Ziya'nın resimlerindeki güneş impressioniste'lerin çok mühim bir mesele olarak ele aldıkları ve pointiliste'lerin didik didik ettikleri güneş değildi.

Nazmi Ziya'nın resimlerinde güneş hiçbir zaman bir mesele halinde çökmemişti.

Onun resimlerindeki güneş sadece bildiğimiz güneşti. Boğaziçini müthiş maviliğe boğarken, karşı sahillerde o mavilikle boy ölçüşecek bir tek renk bırakmadan eriten güneşi, İstanbul'un insafsız güneşi!" 27

Resim 9. Nazmi Ziya Güran, Boğaziçi'nden, Tuval Üzerine Yağlıboya, $67 \times 81 \mathrm{~cm}$, İstanbul Resim Heykel Müzesi.

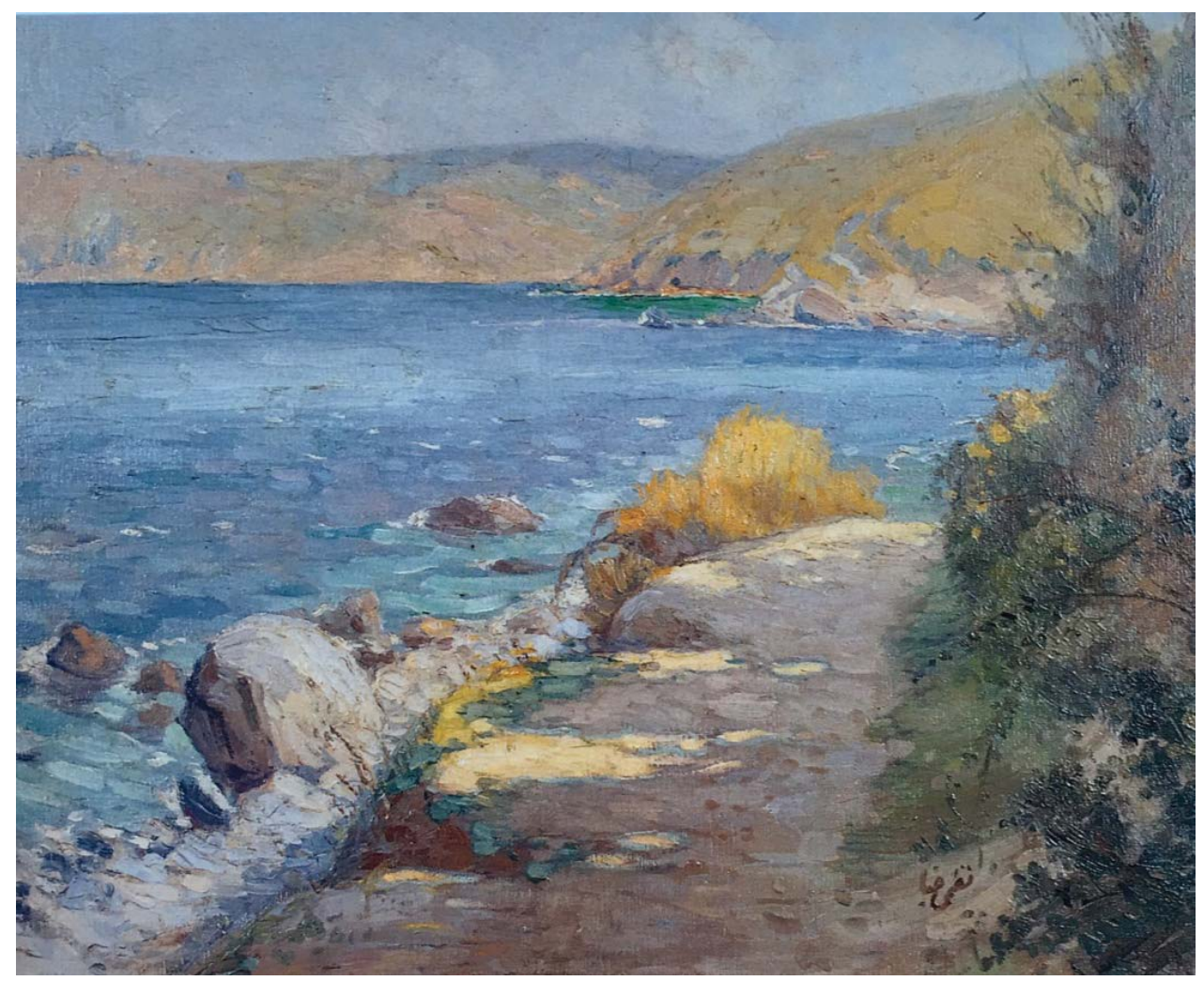

Kaynak: T. Erol, Nazmi Ziya, İstanbul, Yapı Kredi Kültür Yayınları, 1995, s. 234.

Bedri Rahmi'nin bu görüşü, Türk Empresyonistlerinin önemli ismi Nazmi Ziya ile Bat Empresyonistleri arasındaki farka açıklık getirmiştir. Nazmi Ziya için doğa bir enerji sistemi değil, güneşin yarattğı lirik duygularla dolu bir olgudur. ${ }^{28}$

Bu bağlamda İpek Duben Batı resminde Empresyonizm'in biçimsel oluşum sü-

27 A.g.e., s. 153.

28 A.g.e., s. 154. 
recini ve vardığı kavramsal noktayı vurguladıktan sonra Cemal Tollu'nun Türk Empresyonistleri hakkındaki yorumunu şöyle aktarır:

"Empresyonistler temsili resme son verdikleri gibi, denge ve perspektif kurallarını da yıktılar. Renk parçalarından oluşan yeni bir form anlayışı oluşturdular. Hemen belirtmek gerekir ki, ne denli radikal olursa olsun, Bat sanat tarihinde Empresyonizmin biçim betimlemesinin bağlantı noktaları vardır. Raphael ve Michelangelo gibi sanatçılar chiaroscuro kullanmışlar ve plastik forma bağlı kalmışlar; fakat Tiziano, Rembrandt ve 19. yüzyılda Goya, plastik forma karşı, renk tonlarının bileşiminden oluşan formu yaratmışlardı. Empresyonist teknikte ölçü, biçimin renk parçalarından oluşması, çizgi kullanılmamasıydı. Aksi halde form ve renk kayboluyordu. Rengin parçalara bölünmesi geleneksel "mekân" ve "hareket" kavramlarına yeni yorumlar getirdi. 15. yüzyılda Floransa okulu, "mekan"ı içinde figürün betimlendiği bir boşluk olarak kullanmışt, 16. yüzyılda ise Venedik okulu ve Leonardo, çizgisel perspektife hava perspektifini ekleyerek, boşluğu atmosfere dönüştürdü. Renk tonlarıyla atmosferde derinlik (üçüncü boyut) duygusu yaratilıyordu. Empresyonizm, atmosferi renk parçacıklarının titreşimine boğdu. Sonuç olarak, üçüncü boyut yassıldı, daraldı; resim yüzeyi ve yüzeydeki boya önem kazandı. Resimde 'hareket' tüm yüzeyi kapsayan renk parçacıkları arasındaki gerilimin yarattğı yaygın bir titreşim duygusuna dönüştü. Empresyonizmin temelinde, yaşamın, Tanrısız bir dünyada bir enerji sisteminden başka bir şey olamadığı görüşü yatıyordu.

1914'te Nazmi Ziya, Çallı ve Hikmet Onat'ın bu görüşü paylaşmaları düşünülemezdi. Cemal Tollu "Bu neslin ne empresyonizmi, ne de klasik adını verdikleri akademizmi iyi anlamış oldukları düşünülemez" demiştir. Tollu'ya göre bu sanatçıların köklü bir sanat getirdikleri de söylenemezdi. Ona göre bu kuşağın ressamları, "akademik eğitim görmüş ve Empresyonizmin fena tarafını örtük olarak almışlardı. (...) Konulara çeşitlilik getirdikleri gibi "renk ve fırça özgürlüğü" de getirdiklerini söyleyen Tollu,, "Eskilerde sevdiğimiz, ibadet eder gibi, saygı ve telkinle resim yapma ananesini bozduğundan dolayı, Türk resmine zararlı olacak bir çığır açmış gibi telakki etmek mümkün ise de, yeni imkanları bu sarsıntiya borçluyuz", diyordu. Nurullah Berk "orta devir sanatkârları" adını verdiği bu ressamları şöyle anlattyor: "Çallı İbrahim ve arkadaşları memlekete yeni bir resim mefhumu getirmişlerdir. Onların bizde oynadıkları rol Empresyonistlerin Garp sanatındaki rollerine muadil sayılabilir. (...) Zekai, Şeker Ahmet Paşaların ve diğer ilk devre sanatkârlarının ananevi işçiliğinin, akademik paletinin yerine, dağılmış, Empresyonist diyebileceğim normlar, havanın ihtizazlarına karşı hassas, temiz ve parlak bir renk görüşü getirdiler. Bu itibarla bugünkü sanatımızı onlar hazırladılar."'”29 
Cemal Tollu'nun empresyonizmi tam olarak kavrayamadıklarını belirtmiş olduğu Türk sanatçılar biçim betimlemesinde zaman zaman geleneksel desene başvurarak lokal renkler kullanmışlar, akımın esasındaki teknik ve bilimsel özellikleri kaçırmışlardır. "Buna rağmen empresyonizmi taklit eden Türk sanatçısının doğaya karşı ilgi duymaya başlamış olması önemlidir. Saf renkler kullanmakta, koyu tonlarla gölge yapmaktan kaçınmakta, rengi parçalamaya çalışmakta, chiaroscuro kullanmamaya özen göstermekte ısrar eden Türk empresyonistleri için bu çabanın en radikal ve yenilikçi yönü, onlara kendi duyularını izleme uyarısını getirmesidir." 30

Türk resminde rengin olanaklarının oldukça yoğun kullanıldığı ilk ve en önemli dönem, 1914 dönemi yani Çallı Kuşağı sanatçıları olmuştur. İbrahim Çallı, Feyhaman Duran, Namık İsmail, Avni Lifij gibi sanatçılar, akademik etkide olan bir empresyonizmi tercih etmişler, zaman zaman modleyi ve çoğu zaman da modülasyonu kullanmışlardır. Atmosfer etkisi oluşturmak amacıyla, tek renkliliği tercih etmişlerdir. Manzaralarda daha çok rengi özgürce kullanmayı yeğlemişler, fakat rengi doğanın ışığını görselleştirmek için önemsemişlerdir. Özellikle Avni Lifij'in resimlerinde ve poşatlarında renk, bütünlük, armoni ve atmosfer etkisini güçlendirmektedir. Hikmet Onat, Namık İsmail ışığın etkisini vurgulamaya çalışmışlar, rengi bu ışıklılığı etkili bir şekilde sunmak için kullanmışlardır. Dolayısıyla bu dönem sanatçıları doğanın kabuğunu değil, doğadaki ışığın görsel etkisini vurgulamak için renkten yararlanmışlardır.

1916-23 arasında, İstanbul'da düzenli olarak açılan "Galatasaray Sergileri” Cumhuriyet öncesinin başlıca sanat etkinliği olmuştur. Bu sergiler 1923'ten sonra "Ankara Sergileri" adı altında Ankara'da yinelenmeye başlamıştır. Galatasaray ve Ankara sergilerine katılanların büyük çoğunluğu, 1908'de Osmanlı Ressamlar Cemiyeti'nin üyesiydiler. Cemiyet 1921'de "Türk Ressamlar Cemiyeti", 1926'da "Türk Sanayi-i Nefise Birliği" ve 1929'da da "Güzel Sanatlar Birliği” adlarını almıştır. ${ }^{31} 1923$ 'te Cumhuriyet'in kurulmasının ardından gerçekleşen devrimlerle Türkiye'de kültürel alanda büyük bir devinim sağlanmıştır.

\subsection{Müstakil Ressamlar ve Heykeltıraşlar Birliği}

1914 Kuşağı'nın izlenimci tavrının egemen olduğu 11. Galatasaray Sergisi'nde Çelebi ve Kocamemi, ikili resimleriyle bu eğilime karşı bir seçenek oluşturan yeni bir sanat anlayışını ilk kez temsil etmişlerdir. Ali Avni Çelebi ve Ahmet Zeki Kocamemi'nin 1927 'deki bu sergiye katımalarıyla Cumhuriyet sonrası Türk resminin kazanmaya başladığı çağdaş boyut Müstakil Ressamlar ve Heykeltraşlar Birliği'nin 15 Nisan 1929'da Ankara Etnografya Müzesi'nde açtığı 1. Genç Ressamlar Sergisi'yle gelişme göstermiştir. "Adlarını Fransa'da Seurat ve Signac'ın da üyesi olduğu Bağımsız Sanatçılar Derneği'nden (Societe Des Artistes Indipendants) esinlenerek alan Müstakil Ressamlar ve Heykelttraşlar Birliği'nin ilk üyeleri Ali Avni Çelebi, Zeki Kocamemi, Hale Asaf, Muhittin Sebati, Cevat Dereli, Ali Munip (Karsan), Nurullah Cemal (Berk) Şeref Akdik, Refik Fazıl Epikman, Mahmur Cuda,

30 A.g.e., s. 150.

31 A. Çoker, ve K. İskender, "Cumhuriyet Dönemi-Resim”, Eczacıbaşı Sanat Ansiklopedisi, İstanbul, YapıEndüstri Merkezi Yayınları, 1997, s. 370. 
ve heykelci Ratip Aşir Acudoğu'ydu." ${ }^{32} 1914$ Kuşağı'nın izlenimci anlayışını yeterli bulmayan İbrahim Çallı ve arkadaşlarının sağlam bir desenden yoksun olduğunu ve paletlerinin de gelişigüzel renklerle karmakarışık olduğunu düşünen grubun temel amacı bir önceki kuşağın yerleşmiş sanatsal etki ve egemenliklerine karşı bir tepki oluşturmak ve yeni tavırların varlığını ortaya çıkarmakt. Müstakiller'in "geneldeki sanat eğilimleri, Cezanne ve Kübizm geleneğinden kaynaklanan 'inşacı' bir tuş düzeniyle nesnenin yapısını oluşturan kuruluşun resimsel bir düzen içinde bütünleştirilmesiydi. Yapısal bir mekân ve hacim anlayışıyla beslenen bu bakış açısı, en azından tarihsel açıdan dönemini çoktan kapamış bulunan İzlenimcilik'in daha ilerisindeydi." ${ }^{33} 15$ Temmuz 1929'da yayımladıkları broşürde amaçlarının "yeni doğan Türk Resminin gelişmesine ve ilerlemesine yardım etmek, düşün ve teknik alanında daha güçlü yapıtlarla ulusal güzel sanatlara, doğru ilkeler çerçevesinde bir yön verecek layık olduğu düzeye eriştirmek" ${ }^{34}$ olduğunu açılayan Müstakiller, yapıtlarında biçimsel yenilikle yeni içeriği bütünleştirmişlerdir.

Resim 10. Zeki Kocamemi, Mekkare Erleri, 1935, Tuval Üzerine Yağlıboya, 123 x 195,5 cm. M.S.G.S.Ü.İstanbul Resim ve Heykel Müzesi Koleksiyonu.

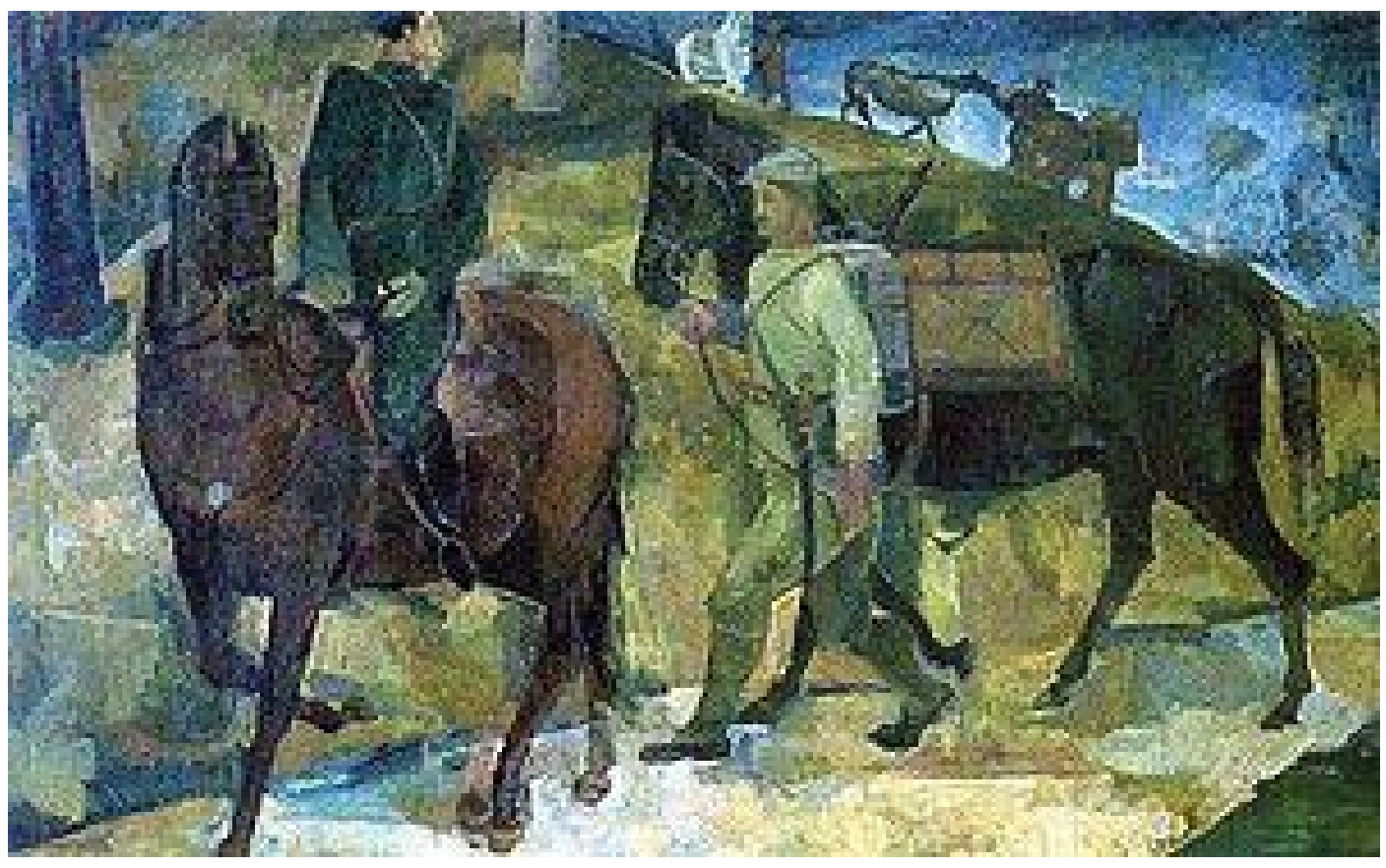

Kaynak: İpek Duben, Türk Resmi ve Eleştirisi, İstanbul Bilgi Üniversitesi Yayınları, İstanbul, 2007, s. 89. 


\subsection{Türk Resminde Konstrüktivizm - Kübizm}

1927'de Hans Hoffman'ın etkisinde Almanya'dan dönen Zeki Kocamemi ve Ali Çelebi, ardından Andre Lhote ve Leger öğretisinden gelen Cemal Tollu ile Nurullah Berk, Türk resmine konstrüktivizmin inşacılığını ve kübizmin biçim anlayışını getirmeye çalıştılar. ${ }^{35}$

“Oysa ki Cezanne'da ilk belirtileri görülen modern düşüncenin mekân ve zaman kavramları, 1930'larda Türkiye'de anlaşılamazdı. (...) Kübizm, yeni teknoloji ve bilgi kuramlarına koşut olarak Cezanne'ın resimde başlattı̆̆ zaman ve mekân anlayışını geliştiriyor, insanın dış dünya ile kurduğu yeni ilişkileri resim yüzeyine yansıttyordu. 'Süreç', 'oluşum', bağımlılık' gibi soyut kavramlarla tanımlanan ilişkiler sistemini benimseyen kübizm, 'ilişkiler' ile uğraşan bir sanat olarak ortaya çıkt: bir olayın değişik yönleri arasındaki ilişkiler; nesne ve boşluk (çevre) arasındaki ilişkiler. Zeki Kocamemi, Ali Çelebi, Cemal Tollu, Nurullah Berk ve Sabri Berkel çoğunlukla, yerel temalara konstrüktivist ve kübist metotları uyguladılar. Modernist düşünceden temellenmeyen sanatçılar, orijinal üslupları ancak biçimsel olarak taklit ediyorlardı. Doğayı silindir ve koni formları ile yorumlamak; modülasyon yerine derinliği renk tuşları ile yaratmak; dolu biçimleri parçalayarak soyutlamak; planları, geleneksel perspektif kurallarını yıkarak üst üste bindirmek, sanatçıların paylaştığı yöntemlerdi. Bu sanatçılar bir süre sonra kübizmin yalınlığından uzaklaşacaklardı. (...) Nurullah Berk, Cemal Tollu ve Zeki Kocamemi, 1940 yılından sonra, mekân parçalamadan kapalı biçimler kullanarak geleneksel düzenlemelere döndüler." ${ }^{\prime 36}$

Sonuçta, Ali Çelebi, Zeki Kocamemi, Cemal Tollu, gibi sanatçılar biçim, form, koımpozisyon ile kübist ve konstrüktivist bir anlayışı benimsemişlerdi. Çalışmalarında renk, bu amaçlarına hizmet edecek şekilde, zaman zaman lokal etkilerle, zaman zaman da bütünlük oluşturma bağlamında, çoğu zaman da monokrom olarak işlevsellik kazanmıştır. Nurullah Berk ise rengi yoğun bir şekilde lokal olarak ve doygun bir şekilde kullanmayı tercih etmiştir. Renk, bu bağlamda çalışmalarının olmazsa olmazı olarak işlevselleşmiş ve Türk resminde renk kullanımı bağlamında önemli bir dönüm noktası olmuştur.

35 i. Duben, Türk Resmi ve Eleştirisi, İstanbul Bilgi Üniversitesi Yayınları, İstanbul, 2007, s. 94.

36 A.g.e., s. 94-95. 
Resim 11. Nurullah Berk, Ütü Yapan Kadın, 1977, Tuval Üzerine Yağlıboya, 100 x 100 cm, Özel koleksiyon.

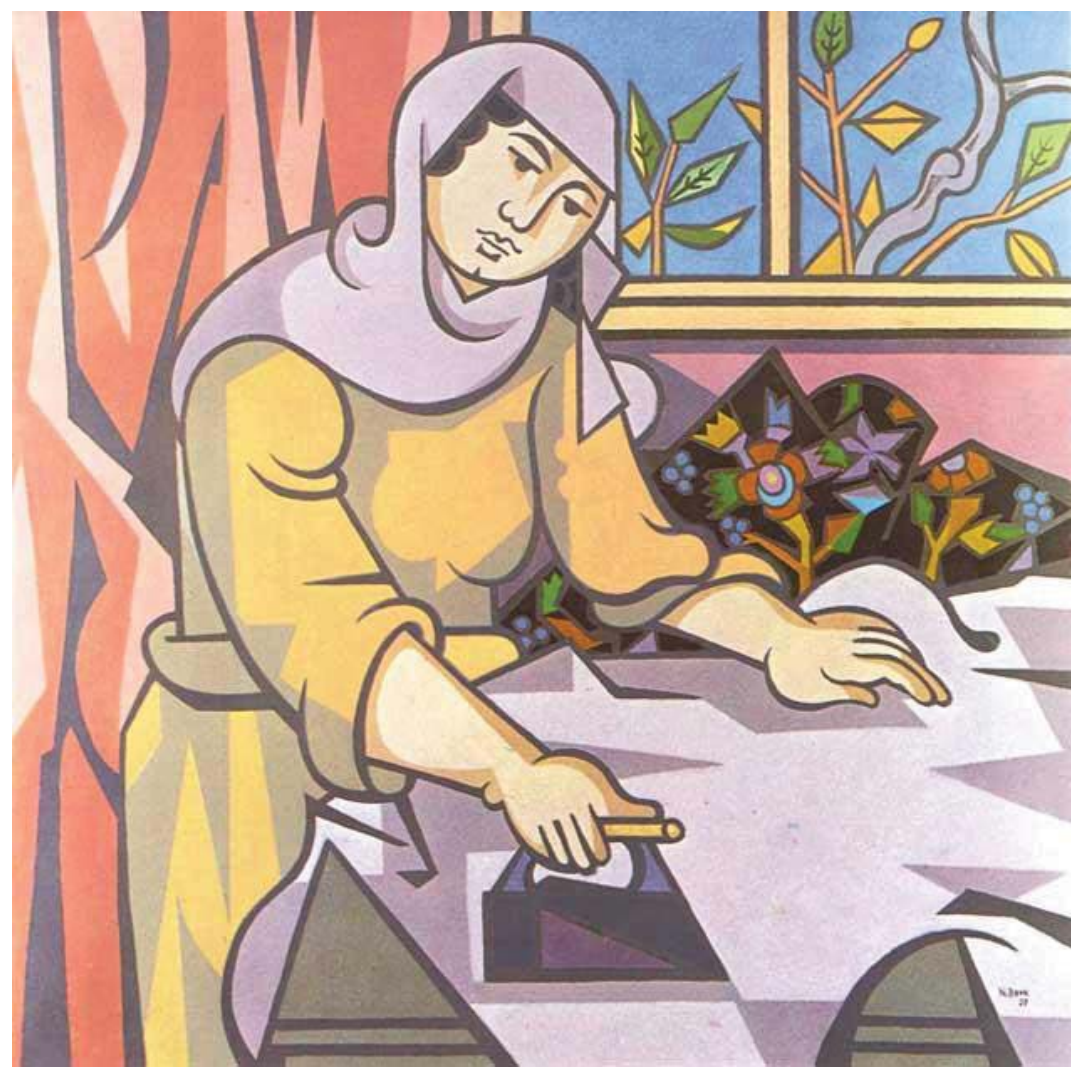

Kaynak: H., Kınaytürk, Nurullah Berk, Türk Ressamları:4, İstanbul, Garanti Bankası Yayınları, 1996, s. 114.

\subsection{Grubu}

1933'te Cemal Tollu, Nurulluh Berk, Zeki Faik İzer, Elif Naci, Abidin Dino ve heykeltıraş Zühtü Müritoğlu tarafindan kurulan D Grubu, 1933-51 arasında düzenli olarak 15'ten fazla sergi açmıştr. "Gruba 4. sergide Bedri Rahmi Eyuboğlu, Arif Kaptan ve Salih Urallı; 9. sergide Hakkı Anlı, Sabri Berkel, Fahrelnissa Zeid ve heykeltıraş Nusret Suman; 15. sergide de Kocamemi katılmıştır. "D Grubu sanatçıları "akademizme ve yapay modernizme karşı, yaşayan sanat topluma iletmeyi ve onların beğenilerini doğru ve çağdaş bir tavra yöneltmeyi" amaçlamaktaydılar." ${ }^{37}$ Her türlü duyusal davranışı reddeden akılcı yaklaşımı benimseyip kendi aralarındaki bireysel üslup farklılıklarına karşın, Türk resmine akılcı ve "aydın" bir yaklaşım getirmek, resimde teknik ve düşünceyi birleştirmek gibi bir amaç çevresinde birleşmişlerdir.

"1914 Kuşağı (Çallı Kuşağı) olarak da tanınan İzlenimci ressamların (İzlenimcilik) resimde deseni yok eden anlayışlarına karşı çıkmışlar, desen yapısını ve kütleselliğini yeniden kurmak için, Rönesans ustalarına dönmeyi benimsemişler, ayrıca

37 A. Çoker ve K. İskender, “Cumhuriyet Dönemi-Resim”, Eczacıbaşı Sanat Ansiklopedisi, İstanbul, YapıEndüstri Merkezi Yayınları, 1997, s. 371. 
Akademizm'e ve körü körüne doğa kopyacılığına da son vermeyi amaçlamışlardır." ${ }^{38}$ Sanat görüşlerinin kübist inşacı eğilimlerin bireşimi niteliğindeki bir biçim anlayışı üstüne temellenmiş olması bakımdan Müstakiller ile aralarında büyük bir ayrılık görülmeyen D Grubu sanatçıları Çallı Kuşağı'na (1914 Kuşağı) da aynı şekilde karşı çıkmışlardı.

"Aradaki tek fark, belki de, görüşlerini daha aşırı ve ödünsüz bir tavırla savunmalarıydı. Bu bağlam içinde sözcülüğünü ettikleri Lhote'un formülleştirilmiş Bireşimsel Kübizm'ine temellenen şematik bir biçimcilik anlayışıyla, ülke ülke sanatını yönlendirme ve yenileme çabaları belli bir zaman için etkili olmuştur. Ancak etkinliklerinin doruk noktasına tırmandığı bir sırada, Lhote'un öğretilerinin Avrupa'da Kübizm'in akademikleştirilmesi anlamına geldiğinin bilincine de çoktan varılmışt. Düşüncedeki birlikteliklerine karşın, D Grubu üyeleri sanatsal planda değişik görüşler taşıyorlardı." ${ }^{39}$

Geleneksel Türk örgelerini kullandığı yapıtlarıyla tanınan ressam, seramikçi ve şair Bedri Rahmi Eyüboğlu'nun kullandığı renkler, seçtiği halk sanat örneklerinin canlılığını taşırlar. Halk örgelerinin biçim ve renk zenginliğini çağdaş teknikleri kullanarak bireşime ulaştırmıştır. ${ }^{40}$ "Bu anlayışla yaptığı çalışmaları giderek renk ve çizginin soyutlama olanaklarını araştırmasıyla birlikte gelişmiştir." ${ }^{41}$

"Resim nedir? Resim, ışığa kavuşan her şeyi büyük bir aşk ile incelemek ve bu aşkı renkler ve çizgiler aracılığı ile insanlara aşılamak sanatıdır." ${ }^{42}$ diyen Bedri Rahmi, resimde 4 ana unsurdan bahseder: Renk, Leke, Çizgi ve Benek.

Bedri Rahmi'nin "Merhaba Renk" isimli yazısının girişi şöyledir:

"Kalamış iskelesinin arkasında güneş batıyordu. ískeleyle tramvay durağı arasında beş on tane, kabadayı çınar vardır. Karakış, ağaçların yapraklarını kökünden kazımış, ince kalın ne kadar dal varsa, hepsi damar damar gökyüzüne çizilmiş. Gökyüzü bir âlem. Güneş, Moda burnunun arkalarında bir yerde batmış olmalı. O taraf, ateş alev yanıyor.

"Kırmızı gülün alı var"diyen Rumeli türküsündeki al, böylesine katmerli bir kırmızı olmalı. Ama, bu belâlı kırmızı, hiç bir ipucu vermeden morarıyor, sonra sezdirmeden turuncu kesiliyor, daha sonra, çınarların uçlarına doğru, turuncu kavuniçine dönüyor, sonunda, daha yukarılara doğru, kâğıt akı kadar aydınlık bir pembe, aynı koyulukta ılık, isimsiz bir mavide karar kılıyordu. Asıl kızılca kıyamet, ulu ağaçların en sık dalları arasında kopuyordu. Gövdelerin ve iri

38 E. Dal, “D Grubu”, Eczacıbaşı Sanat Ansiklopedisi, İstanbul, Yapı-Endüstri Merkezi Yayınları, 1997, s. 416.

39 A. Çoker ve K. İskender, "Cumhuriyet Dönemi-Resim", Eczacıbaşı Sanat Ansiklopedisi, İstanbul, YapıEndüstri Merkezi Yayınları, 1997, s. 371.

40 E. Dal, "Eyuboğlu, Bedri Rahmi", Eczacıbaşı Sanat Ansiklopedisi, İstanbul, Yapı-Endüstri Merkezi Yayınları, 1997, s. 573.

41 A.g.e., s. 573.

42 M. Durmuş, "Bedri Rahmi Eyuboğlu 'nun Şiirlerinde Işık ve Renk Unsuru”, Türkoloji Dergisi, C.14, S.1, Ankara Üniversitesi Dil ve Tarih-Coğrafya Fakültesi, 2001, s. 239-254. 
dalların yan yana gelmesiyle, heybetli nakışlar doğmuştu. Bunların aralarında kalan, en renkli gökyüzü parçalıklarının, renklerinden önce, aydınlıkları fişkırıyordu. Incecik dalların seyrek olduğu yerlerde, demin adını ettiğim renkler, adları sanlarıyle anılıyorlardı. Gökyüzündeki renklerin ipucu vermeden birbirleri içinde erimeleri, olgun bir kavun dilimini hatirlatiyordu. Hani kavunun en tatlı yerinde ateşalev bir renk tutuşur. Bu renk, dilimin dibindeki acı kabuk yeşiline değerken söner. Ama, bütün dilimden gözümüzde kalan bir tek renk tadıdır. Batan güneş kırmızısının birçok renklerden geçtikten sonra, aydınlık bir mavide karar kılması da aynı şeydi.

Derken, bir sürü kuş peydah oldu. Bunlar, ağaç demetlerinin çeşitli dallarına serpildiler. Kimisi seyrek dallardan birisinin tepesine kondu, kimisi de, sık dalların arasında kayboldu.

İcimden "Ah!..» dedim, "nerede bizim Akademideki atelyenin çocukları, şimdi burada olsalardı dört beş derste anlatabileceğim bir çok şeyi, dört beş dakikada anlatabilirdim. Iş̧te, dörtbaşımâmur bir tablo. İşte mağara devrinden günümüzün resmine kadar müzelerde, galerilerde, kitaplarda arayıp taradığımız dört cevher. Iş̧te sanatımızı taşıyan dört direk:

Biri çizgi biri leke biri renk. Dördüncü adıyla sanıyla Benek...

Karşımdaki konuda, hepsi açık-seçik yerli yerinde. Konuda beni derhal durduran, aydınlık gökyüzüne serpilen koyu lekelerdi. Ağır gövdelerden fişkıran binlerce dal, öylesine zengin, öylesine görülmemiş bir nakış örmüşlerdi ki, en ufak bir resim terbiyesi görmüş gözün, bu canım leke düzenini çiğneyip geçmesi imkânsızdı. Demek, bu tablo dört cevherden biri olan leke ile başlıyordu. Onun hemen ardından, pırıl pırıl renkler göze çarpıyordu.

Konunun ikinci kozu renk'ti. Daha sonra, incecik dalların gökyüzüne çektikleri başıboş yüzlerce çizgi. Bunlar da üçüncü planda yer alıyorlardı. Manzaranın tuzu biberi de dalların arasına serpilmiş kuşlar olmuştu. Bunlar da, adına benek dediğimiz dördüncü cevherin ta kendisi idi. Beneğin, çizgi, leke, renk gibi, kendi başına buyruk bir resim elemanı olabileceğine çok zor karar verdim. Bundan on yıl önce, mesleğimizin temel direklerini kuran bu dört elemanı:

«Dört küheylân çeker arabamızı.» diye anlatmış ve öğrencilerimden bunu bir kompozisyonla belirtmelerini istemiştim. Benek üstündeki tereddütlerimi kavrayanlar, öteki atları aynı boyda yaptıkları halde, beneği en arkada, küçücük bir tay olarak belirtmişlerdi. Aradan geçen on yıl, bu tereddütleri sildi. Ve küçük tay da ötekilerin boyuna ulaştı. (...)"43

Etkinlik gösterdiği yıllarda olumlu ve olumsuz tepkilere yol açan D Grubu, zamanın sanatçı ve yazarlarının bir grubu tarafindan Türk resmine canlılık ve yenilik getir-

43 B. R. Eyuboğlu, "Merhaba Renk”, Delifişek (Sanat Yazıları), Ankara, Bilgi Yayınevi, 1975, s. 155-157. 
mekle savunulmuş, bir grubu tarafindan ise grup sanatçılarının resimden anlamadıkları, halkın yeni akımları kabul edemediği öne sürülerek karşı çıkılmıştır.

“Tüm tepkilere karşın D Grubu 1947'ye değin birliğini korumuştur. Grubun nesneleri oldukları gibi kopya eden ve giderek akademikleşen arayışlara karşı çıkması, bir tartışma ortamının doğmasını sağlaması, biçimsel de olsa yeni anlayışları uygulaması ve akademizme karşı tavır alması, dar bir çevreden oluşan resim dünyasına canlılık getirmiştir. D Grubu sanatçıları özellikle grubun dağııışından sonraki çalışmalarıyla Türk resminde ulusal ve özgün olana ulaşmayı amaçlamışlardır. Bireysel çalışma ve araştımalara ortam hazırlamada grup deneyiminin yararı olmuş, kendilerinden sonra gelen ressamlara da bakış açısı kazandırmışlardır." ${ }^{44}$

\section{Resim 12. Bedri Rahmi Eyüboğlu, Aşık Veysel, 1954, Kağıt üzerine guaj, 37x27.}

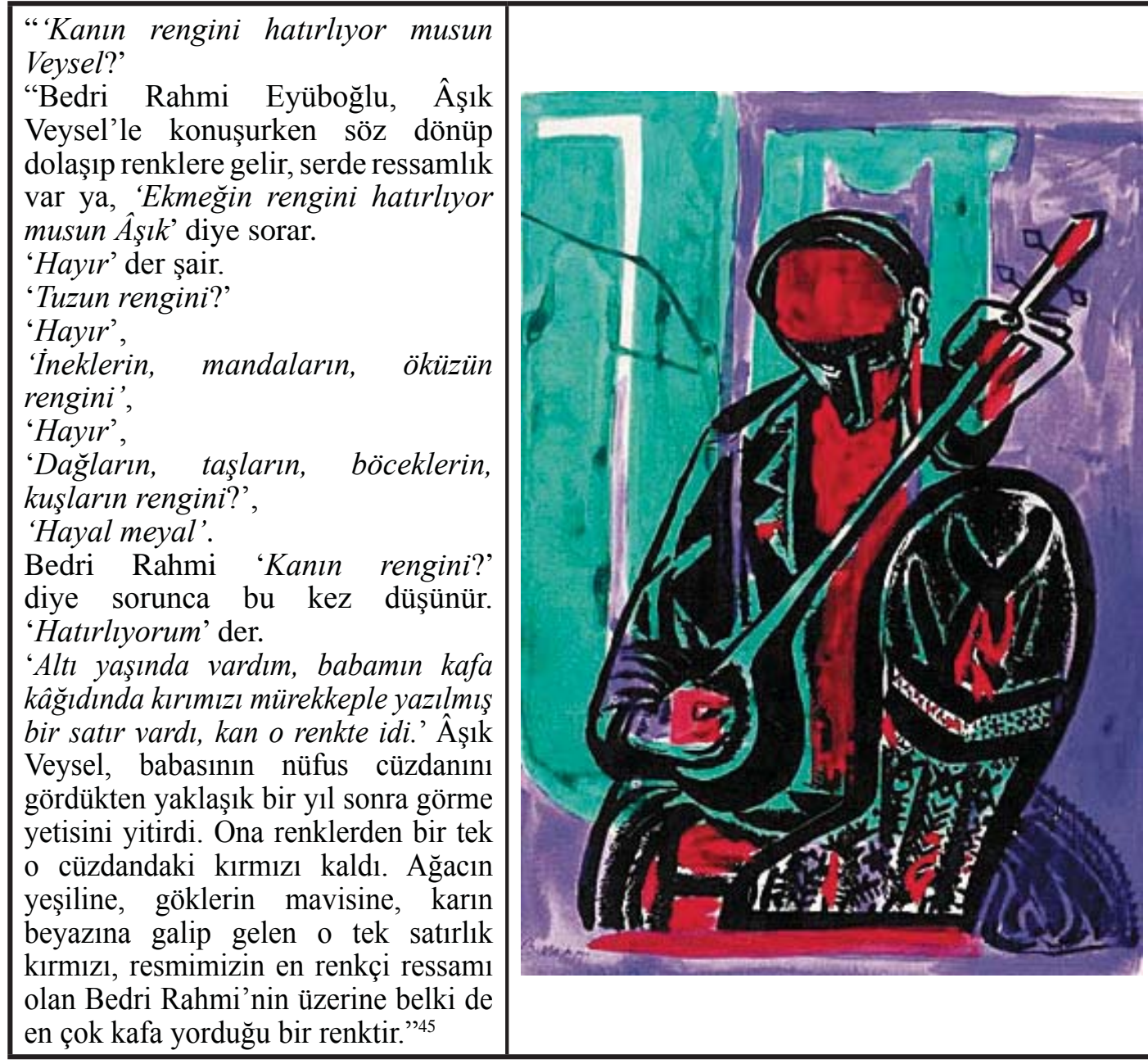

Kaynak: Kırmızı ve Sanat, P Dünya Sanatı Dergisi, Sayı: 50.

Raffi Portakal Antikaclık Müzayede, İstanbul, 2008

44 E. Dal, "D Grubu", Eczacıbaşı Sanat Ansiklopedisi, İstanbul, Yapı-Endüstri Merkezi Yayınları, 1997, s. 417.

45 Kırmızı ve Sanat, P Dünya Sanatı Dergisi, Sayı: 50, Raffi Portakal Antikacılık Müzayede, İstanbul, 2008, s. 62. 
D Grubu sanatçılarıyla birlikte Türk resminde bireyselleşme ve özgürleşme artmış, renk baskın bir şekilde zaman zaman da soyut yüzeyler halinde kullanılmaya başlanmıştır. Nurullah Berk, Sabri Berkel, Arif Kaptan ve Bedri Rahmi Eyüboğlu'nun özgün bireysel yaklaşımları renk kullanımlarıyla etkisini artırmış ve tüm bu sanatçılarla birlikte Türk resminde farklı renk kullanımları görselleşmiş, renk özgürlüğünü kazanmaya başlamıştır. 1914 Kuşağı ile başlayan baskın renk kullanımını, D Grubu'nun yukarıda ifadelendirilen sanatçıları yoğun bir şekilde eserlerinde irdelemiştir. Renk, Türk resminde artık kendi ifadesini ve varlığını göstermeye başlamıştır.

\subsection{Yeniler Grubu}

D Grubu'na karşı, Toplumsal Gerçekçi içeriği savunan bir grup olan Yeniler Grubu, 1940'ta Güzel Sanatlar Akademisi resim hocası Levy'nin öğrencilerinden Nuri İyem, Avni Arbaş, Selim Turan, Nejat Devrim, Kemal Sönmezler, Turgut Atalay ve D Grubu kurucularından Abidin Dino tarafindan oluşturulmuştur. "Öncelikle düşün ve yazın alanında kendini gösteren Toplumsal Gerçekçilik, II. Dünya Savaşı'nın tedirginliği, ekonomik sorunlar ve beraberinde getirdiği toplumsal çalkantılar sonucunda, kültür ve sanat hayatını etkilemiş ve bir ulusal sanat görüşü ağırlık kazanmıştır. Yeniler Grubu bu anlayışın resim sanatındaki yansımasıdır." ${ }^{46}$ Ulusallık, toplumsallık, yöresellik sorununa yeni bir bakış açısı getirmiş olan Yeniler Grubu sanatçıları, yöntem ve teknik açıdan Batı'ya bağlı kalırken, toplumsal içerikli konuları kendi anlayışları doğrultusunda işlemişlerdir.

Yeniler Grubu sanatçıları ortak konuları ele alsalar da biçimsel olarak da desenci yapıları açık-koyuyu temel alan form yaklaşımları temel paydalarıdır. Nuri İyem'in biçim ve formu temel alan bir yaklaşımı vardır. Avni Arbaş deseni önemserken mekanda doygun renkler de kullanmıştır. Selim Turan'ın lirik yaklaşımlarında rengin ana etmen olarak yer almamasıyla beraber soyutlamalarında tek rengin olanakları ve doygun kullanımı fakat yine de desen ve biçimi önemseyişi, Nejat Devrim'in soyutlama ve soyut çalışmalarında açık koyu ile birlikte önem kazanmakta olan rengin farklı ton değerlerinde özünü kaybetmeden doygun olarak bütünlük içerisinde olması, Turgut Atalay'ın biçim, form ve ton eksenindeki çalışmalarında rengin irticalen yer alması, Fethi Karakaş'ın çalışmalarında ise rengin atmosfer etkisi bağlamında yer alması ve Mümtaz Yener'in desenci yaklaşımında rengin lokal ya da atmosfer etkileri olarak kullanılması Yeniler Grubu'nun rengi önemsememekle birlikte daha çok desen ve form eksenli yaklaşımlarının ifadesidir. Ancak Ferruh Başağa'nın çalışmalarında renk olmazsa olmazdır. Soyutlamacı yaklaşımlarında açık-koyu, ışık gölge etkilerini tek rengin varyasyonları ya da tamamlayıcı renklerin oluşturduğu karşıtlıklarla görselleştirir.

46 N. Arslan, "Yeniler Grubu", Eczacıbaşı Sanat Ansiklopedisi, İstanbul, Yapı-Endüstri Merkezi Yayınları, 1997, s. 1939. 
Resim 13. Nuri İyem, Adalet Cimcoz Portresi, 1952, Duralit Üzerine Yağlıboya, 75x65cm.

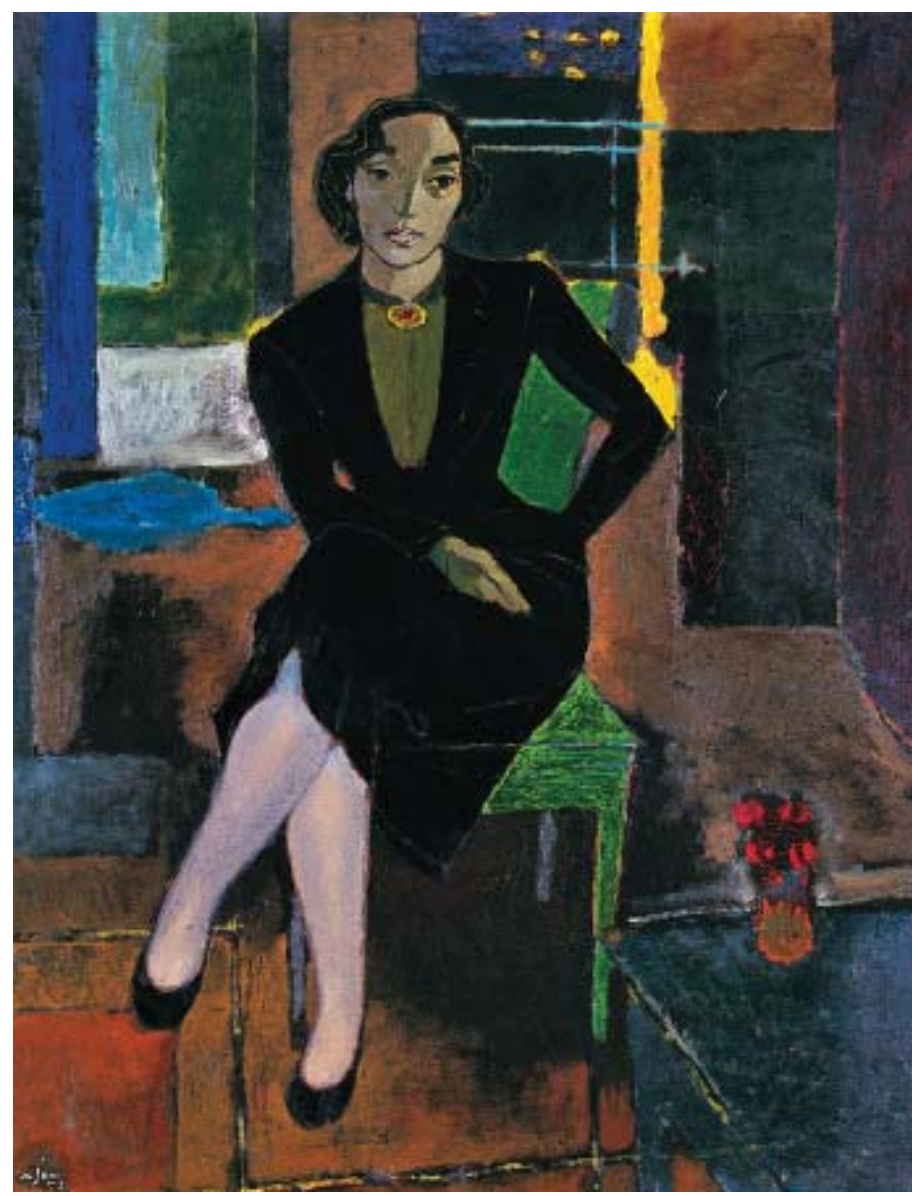

Kaynak: "Nuri lyem 100 Yaşında / Portre" Sergisi, İstanbul, Evin Sanat Galerisi, 2015.

Sonuç olarak denebilir ki Yeniler Grubu için genelde renk yardımcı öğe olarak kullanılmış fakat yine de irticalen kullanımıyla da dikkat çekmiştir.

\subsection{Onlar Grubu}

Mayıs 1947'de Bedri Rahmi Eyüboğlu'nun öğrencilerinden Ivy Stangali, Leyla Gamsız, Hulusi Sarptürk, Mustafa Esirkuş, Nedim Günsur, Fahrünnisa Sönmez, Turan Erol, Orhan Peker, Mehmet Pesen ve Fikret Otyam tarafindan kurulmuş olan Onlar Grubu sanatçılarının amaçları, Anadolu'nun geleneksel nakış öğeleriyle çağdaş Bat resminin anlatım biçimlerini birleştirerek, doğadan ve yaşanan gerçek çevreden seçtikleri konuları yöresel bir dil ve çağdaş sanatın soyutlama anlayışıyla işlemektir. ${ }^{47}$ Onlar Grubu, Bedri Rahmi'nin sanata ve resme ait düşünceleriyle yapıtlarından etkilenmiştir. İstanbul'da Güzel Sanatlar Akademisi'ndeki eğitimleri süresince "Batılı ustaları çok iyi tanımış, Dürer ve Leonardo Da Vinci gibi ressamların desenleri üzerinde çalışmış, Türk bezeme sanatlarından aldıkları örgelerle, yöresel çizgileri bu sağlam temel üzerine oturtmuşlardır. 1947'de GSA'nın yemekhanesinde açtıkları ilk serginin iki afişinden birinde El Greco'nun

47 N. Arslan, "Onlar Grubu”, Eczacıbaşı Sanat Ansiklopedisi, Eczacıbaşı Sanat Ansiklopedisi, İstanbul, YapıEndüstri Merkezi Yayınları, 1997, s. 1376. 
bir insan figüründen ayrınt, öbüründeyse bir Anadolu kilimi deseni bulunmaktaydı. Bu afişler bir anlamda Doğu ve Batı'nın sanat bireşimi gibiydi." ${ }^{48}$ Topluluk ortak bir sanat görüşü geliştirmekle birlikte üyelerin her biri kendi özgün çizgisini korumuştur. Onlar Grubu, Türk Resim Sanatında önemli bir toplumsal hareket olarak dikkati çekmiş ve Türk resimine önemli katkıda bulunmuşlardır.

Onlar Grubu da Yeniler Grubu'ndan farklı olmayan biçim ve renk kullanımını yeğlemişlerdir.

\subsection{Soyut Eğilimler}

Figüratif sanat kadar yaygın bir değer kazanamamış olmakla birlikte soyut resim uygulamaları, Türk resmini çağdaşlaştıran önemli bir yönelim olmuştur.

“II. Dünya savaşı Avrupa'sında Kübizm sonrası estetiğine dayanan biçim anlayışı yerini bütünüyle soyut sanata ve özellikle de "Taşizm" ya da Soyut Dışavurumculuk gibi yaklaşımlara bırakmıştır. Kimi çevrelerce Sartre ve Camus gibi düşünür-yazarların kişiliğinde güncelleşen Varoluşçuluk düşüncesinin sanattaki karşılığı olduğu ileri sürülen bu akımların Türk sanatına yansıması 1950'lerin ortalarına rastlar. Bu gelişmede, savaş sırasında kendi içine kapanan Türkiye'nin 1950'lerle birlikte Batı'ya ve çok partili demokrasiye açılma politikasını benimsemesinin büyük bir payı vardır. Bu açılma bağlamında Türk sanatının Batida tanınmasını sağlamak amacıyla 1948'de Amsterdam'da Ulusal Türk Sanat Sergisi; 1954'teyse Atina, Belgrad, Moskova ve Leningrad (St. Petersburg) gibi kentlerde Çağdaş Türk Sanat Sergisi gibi sergiler açılmıştır. Öte yandan, Türkiye'nin bir yıl önce (1953) üyeleri arasına katıldığı Uluslararası Sanat Eleştirmenleri Derneği (AICA) 5. Kongresini 1954'te İstanbul'da yapmış; kongre nedeniyle aralarında Paul Firens, LionelloVenturi, Pierre Francastel, Read, Jaques Lassaigne, J. J. Sweny, J. Leymarie ve Werner Hoffmann'ın da bulunduğu ünlü sanat yazarları ve eleştirmenler İstanbul'a gelmişler ve Türkiye'de kaldıkları sürece Türk sanatıyla yakından ilgilenmişlerdir. Bu arada bir bankanın düzenlediği 'Türkiye'de İş ve Üretim' konulu yarışmalı sergide Read, Venturi ve Firens'dan oluşan seçici kurulun Aliye Berger'in Güneş adlı soyut resmini birincilikle ödüllendirmesi sanat çevrelerinde ilk anda büyük bir tepki yaratmış; Bedri Rahmi ve Cemal Tollu gibi bazı ressamlar bu kararı eleştirmişlerdir." ${ }^{49}$

Soyut anlayışa yönelen ilk sanatçılar Cemal Bingöl, Nejat Devrim, Halil Dikmen, Ferruh Başağa, Arif Kaptan, Adnan Turani, Lütfü Günay ve Adnan Çoker olarak sıralanabilir.

“Lütfü Günay ve Adnan Çoker'in Şubat 1953'te Ankara'da Dil ve Tarih Coğrafya Fakülte'sinde ve İstanbul'da Maya Galerisi'nde, bir yıl

48 A.g.e., s. 1376.

49 A. Çoker. ve K. İskender, "Cumhuriyet Dönemi-Resim", Eczacıbaşı Sanat Ansiklopedisi. Yapı-Endüstri Merkezi Yayınları, İstanbul, 1997, s. 373. 
sonra da gene Ankara'da Dil ve İstanbul'da Maya Galerisi'nde, bir yıl sonra da gene Ankara'da Helikon Galesi'nde, 'Non-Objektif' Başlığı altında açtıları sergiler, soyutlama yolunda atılmış ilk adımlar arasında sayılır. Bu ikiliyi Cemal Bingöl'ün Helikon'da açthğı soyut sergi izlemiş; 1954'te İstanbul, Şehzadebaşı'ndaki Kuyucu Murad Paşa Medresesi'nde 20 kadar sanatçının kathlımıyla açılan resim heykel sergisiyse bu anlayışın ilk toplu gösterilerinden biri olmuştur. Sergide Kuzgun Acar, Lütfü Günay ve Adnan Çoker gibi adların yanı sıra Nuri İyem ve Ferruh Başağa gibi 'eski' Yeniler de vardı. Soyut anlayış kısa bir süre sonra Devlet Resim Heykel Sergilerinin başıca eğilimi durumuna gelirken, Sabri Berkel, Zeki Faik İzer, Şemsi Arel, Abidin Elderoğlu, Şadan Bezeyiş, Hasan Kavruk, Hamit Görele gibi sanaţ̧ıların da soyuta yöneldikleri görülür." ${ }^{50}$

Resim 14. Aliye Berger, Güneşin Doğuşu, 1954, tuval üzerine yağlıboya, 200x300cm, Yapı Kredi Koleksiyonu.

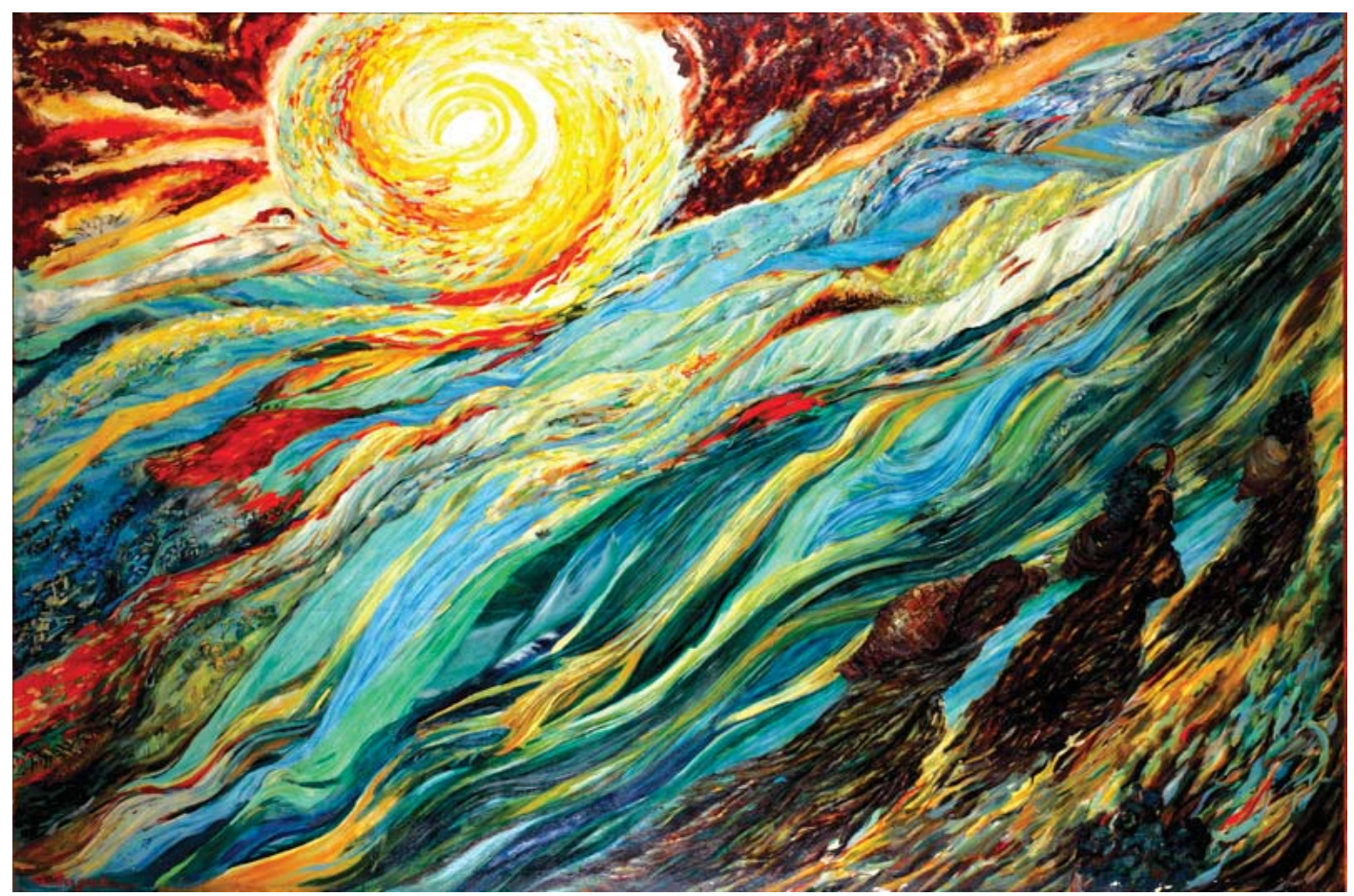

Kaynak: Aliye Berger Sergi Kataloğu, İstanbul, Devlet Güzel Sanatlar Akademisi, 1975, Kapak.

Soyut resmin Bat'daki gelişim ve çeşitlenme biçimleriyle Türkiye'deki gelişmesi ve yönlenişleri benzer özellikler taşımaktadır. Türk sanatında soyut resim ve temsilcileri, geometrik soyutlamacılar, lirik soyutlamacılar, geometrik non-figüratif ve lirik non-figüratif olarak sınıflandırılabilir. Geometrik-soyutta, firça işçiliği ve boya dokusu dışlanırken; lirik soyut, serbest firça işçiliğine dayanan kendiliğinden ve hatta dışavurumcu sayılabilecek bir anlayıştır. Fakat tek bir anlayış içinde çalışmalarını sürdüren çok az sanatçı vardır. Soyut eğilimlerin hızla gelişme gösterdiği süreçte

50 A.g.e., s. 373. 
kesin bir akım bütünlüğü bulunmaz, akımlar arasında geçişler görülür.

"Sabri Berkel ve Cemal Bingöl gibi ressamlar geometrik-soyut (Geometrik Soyutlama), Zeki Faik İzer, Lütfü Günay, Adnan Turani ve 1970'lere değin de Adnan Çoker lirik soyut (Anlatımcı Soyutlama), Soyut Dışavurumcu ya da Hareketli Soyut gibi çeşitli adlarla tanımlanan eğilimlerin temsilcileri sayılırlar. Bunlar dışında Şemsi Arel, Abidin Elderoğlu, ve bazı yapıtlarıyla da Sabri Berkel, 'kaligrafi' ve 'hat' sanatından yola çıkarak, soyut biçimi geleneksel bir görsellikle bağdaştırmaya yönelik girişimleriyle ilgi çekmişlerdir." ${ }^{51}$

1970'lerde Soyut sanata gösterilen ilgi hızla azalmaya başlamış soyutçuların çoğu figüratif anlayışlara dönmüşlerdir.

Devrim Erbil o yıllara nasıl gelindiğine dair şöyle bir anekdot sunar: "Renkli resimleri gösteren araç, gereç, televizyon gibi, yayın gibi, hiç bunların olmadığı bir dönemde kaldı ki yine Bedri Rahmi'nin bir sözüyle; 'ben, Akademi'yi bitirinceye kadar iki tane renkli resim gördüm' dedi. Biri Van Gogh'un 'Postallar'ıydı, diğeri de Gauguin'in bir resmi." 52 Bunun üzerine, 60'lı yıllar Türk Resim Sanatna, Ali Akay, şöyle attfta bulunur: “...bir büyük düşünce dünyası, fikir dünyası, fikir tarihi içindeki bu yerin, evrenselleştirilmeye çalışılan bu yerin çok ilginç bir şekilde, renkli resim iki tane görmüş, siyah-beyaz, boyutu bilinmeyen bat sanat tarihi resimlerine bakarak, ustaların izinden gidilmiş bir dünya çıkıyor karşımıza." ${ }^{53}$ Bu sözler Türk resmindeki gelişim sürecinin ve gelinen noktanın özeti gibidir.

1961'de aldığı burs ile ABD’ye giderek çalışmalarını yurtdışında sürdürme firsatı bulan Bedri Rahmi, bu dönemde zengin renkler ve soyut biçimlere yönelmiştir. Aydın Ayan, Bedri Rahmi'nin soyut eğilimindeki döneminden şöyle bahseder: “Bedri Rahmi Eyüboğlu, 60-70 döneminde Amerika'ya gidip de Rothko'dan etkilenme sürecinde artık doğaya yönelme değil, soyutlamaya değil, tümüyle soyuta yöneliyor. Ama bu soyuta yönelme döneminde bile yerden bulduğu çakıl taşını, deniz kenarından bulduğu, doğada bulduğu kumla şunu, bunu, Anadolu'da bulduğu kilimi ekliyor çalışmasına. (...) 'ben kendimi 30 lu yıllar 40 /ı yıllarda bulmuştum' der. Yani tavrını o zamanlarda ortaya koymuştu, coşkusunu ...ortadaydı. Ama 60-70 dönemi için zaman zaman renkçi mi renkçidir, zaman zaman acaba dediği olmuştur. Çok güzel ve renkçi resimler yapmıştır, çok yaratıc şeyleri vardır yaptıklarında ama tümüyle soyuta yaklaştiğı, soyutu denediği dönem o dönemdir." 54

51 A.g.e., s. 373.

52 D. Erbil, Bedri Rahmi Eyüboğlu Sempozyumu, İstanbul, MSGSÜ, 2011.

53 A. Akay, Bedri Rahmi Eyüboğlu Sempozyumu, İstanbul, MSGSÜ, 2011.

54 A. Ayan, Bedri Rahmi Eyüboğlu Sempozyumu, İstanbul, MSGSÜ, 2011. 
Resim 15. Bedri Rahmi Eyüboğlu

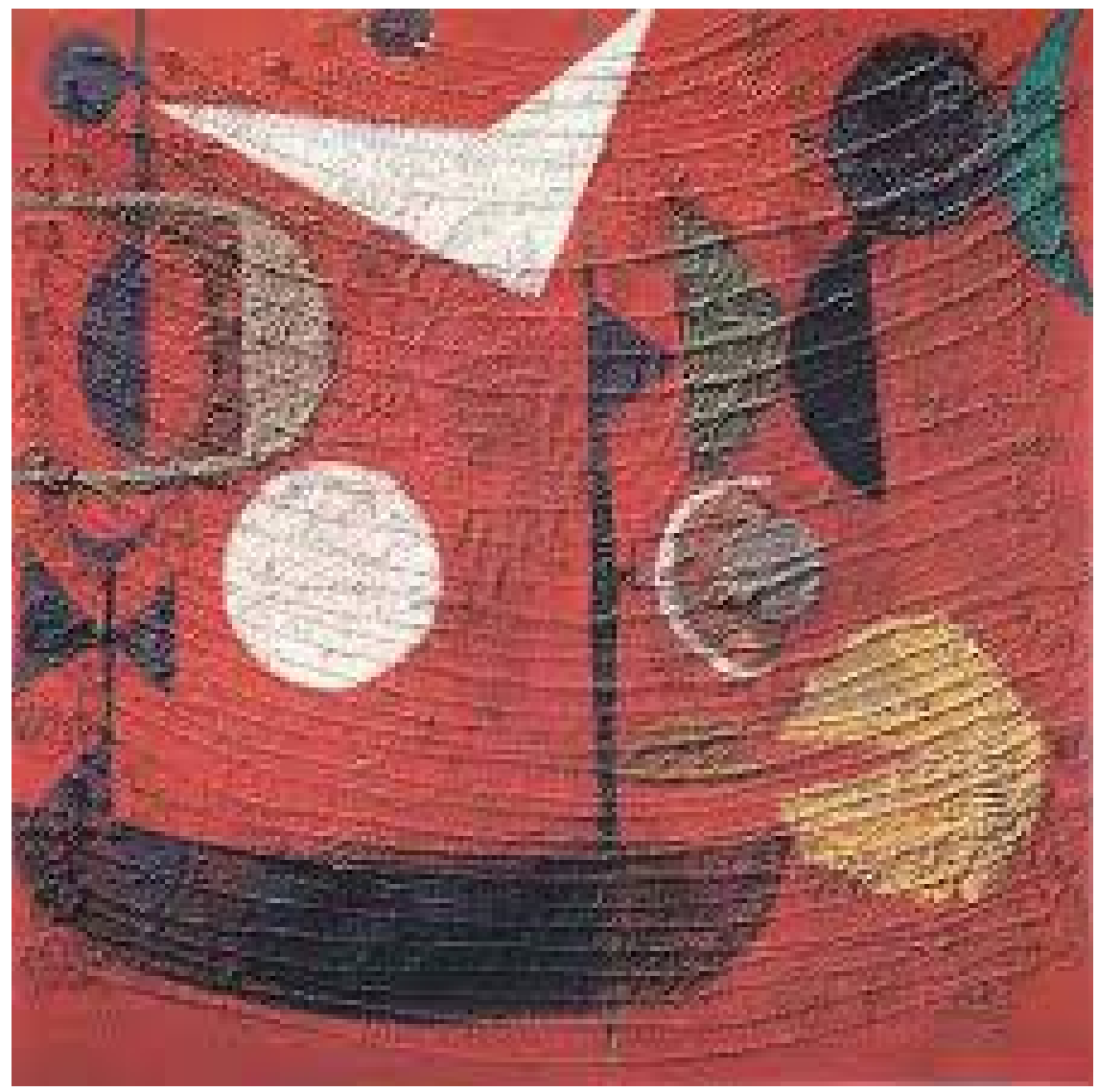

Kaynak: Aydın Ayan Arşivi

Soyut eğilimin bir diğer temsilcisi Ferruh Başağa'nın resimlerinde de rengin, özgürlüğünü kazanmak için önemli bir adım atmış olduğu görülür. Nazan İpşiroğlu, Başağa'nın yapıtlarında ilk resimlerinden bugüne renk açısından bakıldığında göze çarpan değişimi söyle aktarır:

"Renkler giderek aydınlanmış, ışıldamaya başlamış. İlk resimlerinde genellikle koyu renkler ağılıkta. İster manzara, ister portre, konu ne olursa olsun resimlerin hüzünlü bir havası var. 50'li yılların sonunda ve $60^{\prime}$ Iı yıllardan öteye renkler giderek aydınlanıyor. Koyu renkli resimlerde bile resmin ortasındaki, sonsuzluğun simgesi olarak yorumlayabileceğimiz boşluğu vurgulayan aydınlık renk alanı ilk dönem resimlerindeki hüznü dağıtıyor. Kişi yaşlandıkça genellikle dünyası daralır, kararır. Başağa tam tersine yaşlandıkça kendine aydınlık, güneşli, sıcak bir kurgusal dünya yaratmış. Neşeli bir dünya ve resimlerindeki hızlı ritimlere karşın dingin bir dünya. Soğuk renklerle dile getirilmiş olduğunda bile, araya giren sıcak renkli geometrik biçimler ya da rastlantıymış gibi bir yerlerde sıkışıp kalmış küçücük üçgenlerle bu dünya sıcaklığından hiçbir şey yitirmiyor. Bunu kendisine söylediğimde iki nedeni olabileceği yanıtını verdi. Biri, Leopold Levy'nin öğrencisi olarak onun etkisi olabileceği, öteki gençliğindeki yaşam koşullarının getirdiği sıkıntılardan kaynaklana- 
bileceği. Gerçekten o dönemde yaptiğı resimlerde Levy'nin renkleri belirleyici olmuş gibi görünüyor. Zaman içinde bu etkiden sıyrılmış. Kendi özgün renk dünyasını yaratmış. Kuşkusuz bunda da yaşam koşullarındaki olumlu değişmenin ve sanatsal arayışlarında yolunu bulmuş olmanın getirdiği rahatlamanın etkisi var." ${ }^{55}$

İpşiroğlu, Başağa'nın resimlerinde biçimlendirme öğeleri arasında, resimleri müziğe yaklaştıran iki temel öğe olan "ritim ve renk"in kompozisyonun yapısında ağırlıklı bir yer aldığını vurgular. "Daha ilk manzara resimlerinde, doğadan yaptıklarında Başağa'nın ritim ve renk duyarlılığı kendini belli ediyor. Resim soyutlamaya yöneldiği oranda kompozisyon içinde ritim önem kazanıyor ve giderek geometrik biçimlerle, renk alanlarıyla, dahası ışıkla bütünleşerek doğrudan kompozisyonun yapısını oluşturuyor." 56

Resim 16. Ferruh Başağa, Soyut Kompozisyon, 1965, 75x75cm, Tuval üzerine yağlı boya, Leon Kandiyoti koleksiyonu.

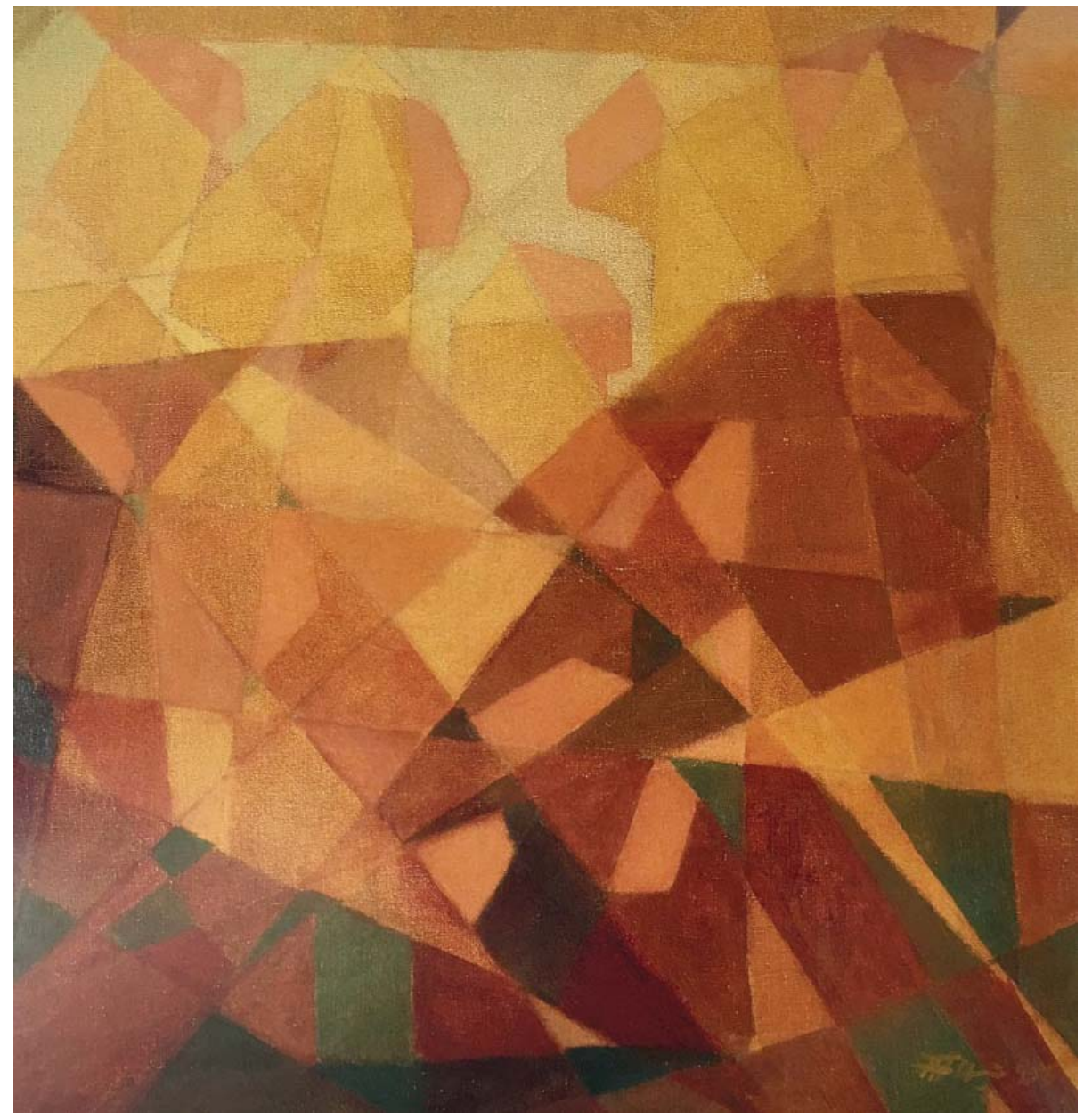

Kaynak: K. Giray, Ferruh Başağa. İstanbul, MAS Matbaacılık A.Ş., 2003.

55 N. İpşiroğlu, Görsel Sanatlarda Alımlama ve Sanatlararası Etkileşim, İstanbul, Hayalperest Yayınevi, 2013, s. 170.

56 A.g.e., s. 173. 
Soyutlama ve soyut eğilimleri olan sanatçılardan Cemal Bingöl, açık-koyunun etkisindeki çalışmalarında renkleri alanlar/yüzeyler halinde doygun bir şekilde, Arif Kaptan ise rengi serbest ve lirik olarak uygulamıştır. Adnan Turani çizgi temelli renk kontrastlıkları yaratırken ve serbest sürüşler kullanmıştir. Adnan Çoker rengi ötelerken, Sabri Berkel biçim ve renk esaslı çalışmalar ortaya koymuştur. Zeki Faik İzer renkli çizgileri esas alırken, Berger ve Zeid renkle doygun ve lirik etkiler elde ettikleri bir atmosferik kullanım oluşturmuşlardır. Sonuçta renk kullanımı ve rengin olanakları Türk resim sanatında bu sanatçılarla birlikte önemli hale gelmiş ve sonraki sanatçılara bir kılavuz oluşturmuştur.

1960 'I yıllardan bu yana Türk resim sanat, figüratif, soyutlama ve soyut yaklaşımlar ve ayrıca pop ve kavramsal eğilimlerle çok yönlü ve hareketli bir süreç yaşamış ve yaşamaktadır. Dolayısıyla farklı eğilimler bireysel yönelimleri de ortaya çıkarmıştır, kendi varlıkları ve özellikleri bağlamında yapıt üreten sanatçılar ortaya çıkmıştır. Buna bağlantılı olarak da farklı farklı biçimsel yapılar sanatçıların yapıt üretiminde etken olmaktadır.

\section{SONUÇ}

Türk minyatür sanatında rengin bir amaç olmamakla birlikte zaman zaman biçimleri daha etkili kılmak ve bir hiyerarşi yaratmak için önem kazanmış olduğu görülür. Nesne ya da figürlerin kendi öz renkleri, lokallikleri dikkate alınarak betimlemeler oluşturulduğu gibi, rengin sembolik etkileri de vurgulanmıştır.

Türk resminin ilk ve en önemli figüratif çalışmalarını üreten Osman Hamdi Bey, biçime forma önem vermiş, rengi çok kontrollü ve tasarruflu kullanmıştır. Aynı zamanda lokal renk onun resimlerinde vazgeçilmezdir. Şeker Ahmet Paşa'nın çaIışmalarında lokal rengin etkinliği azalmakta, monokrom (tek renklilik) etkilerin yoğun bir şekilde kullanımı gözlenmektedir. Çallı Kuşağı'na geçiş oluşturan Hoca Ali Rıza ve Halil Paşa gibi ressamlar hem ton hem de izlenim etkileri elde etmişlerdir. Ayrıca renk, onlar için bütünlük sağlayıcı bir unsur olmuştur.

1914 Kuşağı yani Çallı Kuşağı, Türk resminde rengin olanaklarının oldukça yoğun kullanıldığı ilk ve en önemli dönemdir. İbrahim Çallı, Feyhaman Duran, Namık İsmail, Avni Lifij gibi sanatçılar, zaman zaman modle ve çoğu zaman da modülasyon tekniklerini kullanarak akademik etkide olan bir empresyonizme yönelmişlerdir. Atmosfer etkisi oluşturmak amacıyla, tek renkliliği tercih etmişlerdir. Manzaralarda daha çok rengi özgürce kullanmayı yeğlemişler, fakat rengi doğanın ışığını görselleştirmek için önemsemişlerdir. Özellikle Avni Lifij'in resimlerinde ve poşatlarında renk, bütünlük, armoni ve atmosfer etkisini güçlendirmektedir. Hikmet Onat ve Namık İsmail ışığın etkisini vurgulamaya çalışmışlar, rengi bu ışıkıılığı etkili bir şekilde sunmak için kullanmışlardır. Dolayısıyla bu dönem sanatçılarının doğanın kabuğunu değil, doğadaki ışığın görsel etkisini vurgulamak için rengi etkili bir biçimde kullanmış oldukları görülür.

Müstakiller yani, Ali Çelebi, Zeki Kocamemi, Cemal Tollu, gibi sanatçılar biçim, form, kompozisyon ile kübist ve konstrüktivist bir anlayışı benimsemişler, doğrudan ya da dolaylı rengi hedeflememişlerdir. Yine de çalışmalarında renk, bu amaçlarına hizmet edecek şekilde, zaman zaman lokal etkilerle, zaman zaman 
da bütünlük oluşturma bağlamında, çoğu zaman da monokrom olarak işlevsellik kazanmıştır. Nurullah Berk ise rengi, yoğun bir şekilde lokal olarak ve doygun bir şekilde kullanmayı tercih etmiştir. Renk, bu bağlamda çalışmalarının olmazsa olmazı olarak işlevselleşmiş ve Türk resminde renk kullanımı bağlamında önemli bir dönüm noktası olmuştur.

D Grubu sanatçıları rengi baskın bir şekilde zaman zaman da soyut yüzeyler halinde kullanmaya başlamıştir. Nurullah Berk, Sabri Berkel, Arif Kaptan ve Bedri Rahmi Eyüboğlu'nun özgün bireysel yaklaşımları, renk kullanımlarıyla etkisini artırmış ve tüm bu sanatçılarla birlikte Türk resminde farklı renk kullanımları görselleşmiş, renk özgürlüğünü kazanmaya başlamıştır. 1914 Kuşağı ile başlayan baskın renk kullanımını, D Grubu'nun yukarıda ifadelendirilen sanatçıları yoğun bir şekilde eserlerinde irdelemiştir. Türk resminde bireyselleşme ve özgürleşme artmış ve renk artık kendi ifadesini ve varlığını göstermeye başlamıştır.

Yeniler Grubu sanatçıları biçimsel olarak desenci bir yapıda, açık-koyuyu temel alan bir form yaklaşımında buluşurlar. Nuri İyem resimlerinde biçimi ve formu temel almıştır. Avni Arbaş'ın deseni temel alırken mekanda kullandığı doygun renkleri, Selim Turan'ın lirik yaklaşımlarında ana etmen olarak renge yer vermesi fakat soyutlamalarında tek rengin olanakları ve doygun kullanımı ile yine de desen ve biçimi önemseyişi dikkat çekicidir. Nejat Devrim'in soyutlama ve soyut çaışmalarında açık koyu ile birlikte renk önem kazanmakta, farklı ton değerlerindeki renkler özünü kaybetmeden doygun olarak bütünlük içerisinde yer almaktadır. Turgut Atalay'ın biçim, form ve ton eksenindeki çalışmalarında rengin irticalen yer alması, Fethi Karakaş'ın çalışmalarında ise rengin atmosfer etkisi bağlamında kullanılması, Mümtaz Yener'in desenci yaklaşımına rengin lokal ya da atmosfer etkileri olarak katkıda bulunması, Yeniler Grubu'nun rengi önemsemekle birlikte daha çok desen ve form eksenli yaklaşımlarının ifadesidir. Ancak soyutlamacı yaklaşımlarında açık-koyu, ışık gölge etkilerini tek rengin varyasyonları ya da tamamlayıcı renklerin oluşturduğu kontrastlıklarla görselleştiren Ferruh Başağa'nın çalışmalarında ise renk olmazsa olmazdır.

Onlar Grubu için rengin irticalen kullanımı dikkat çekmekle birlikte, genelde renk tamamen yardımcı öğe olarak kullanılmıştır. Ferruh Başağa'da ise renk, özgürlüğünü kazanmak için önemli bir adım atmıştır.

Cemal Bingöl'ün, açık-koyunun etkisindeki çalışmalarında renkleri, alanlar/yüzeyler halinde doygun bir şekilde uygulaması, Arif Kaptan'ın rengi serbest ve lirik kullanımı, Adnan Turani'nin çizgi temelinde renk kontrastlıkları ve serbest sürüşleri, Adnan Çoker'in rengi ötelemesi, Sabri Berkel'in biçim ve renk esaslı çalışmaları, Zeki Faik İzer'in renkli çizgileri esas alması, Berger ve Zeid'in renkle doygun ve lirik etkiler elde ettiği atmosferik kullanım soyutlama ve soyut eğilimlerin Türk resminde renk bağlamında yer almasını sağlamış, sonuçta renk kullanımı ve rengin olanakları Türk resim sanatında bu sanatçılarla birlikte önemli hale gelmiş ve sonraki sanatçılara bir kılavuz oluşturmuştur.

Sonuç olarak Türk resim sanatında gruplar bağlamında, bazı istisnalar olsa da genelde Batı sanatındaki kullanımının bir yansıması olarak görselleşmiş olan renk kullanımı, ancak bireysel özgünleşme arayışında olan sanatçılarda daha deney- 
sel ve özgür bir şekilde ortaya çıkmıştir. Genelleme yapılacak olursa, Türk resim sanatında sanatçıların yapıtlarında renk, baskın bir şekilde yer almış fakat başlı başına ana öğe ya da ana biçimsel yapı, formun maddesi ya da temel yapısı olarak belirgin bir şekilde işlev kazanmamıştr. Nitekim, 1960'lara dek; renkli resimleri gösteren araç, gereç, televizyon ve basılı yayının bulunmadığı bir dönemde, birkaç taneden fazla renkli resim görmeden, siyah-beyaz, boyutu bilinmeyen bat sanat tarihi resimlerine bakarak, ustaların izinden gidilmiş bir dünya olan Batı anlayışına dönük Türk resim sanatının, bir büyük düşünce dünyası, düşünce tarihi içindeki yerini evrenselleştirilmeye çalışması ve bunu başarması hayranlık uyandırıcıdır. 


\section{KAYNAKÇA}

Akay, A., Bedri Rahmi Eyüboğlu Sempozyumu, İstanbul, MSGSÜ, 2011.

Arslan, N., "Yeniler Grubu", Eczacıbaşı Sanat Ansiklopedisi, İstanbul, Yapı-Endüstri Merkezi Yayınları, 1997, s.1376, 1939.

Ayan, A., Bedri Rahmi Eyüboğlu Sempozyumu, MSGSÜ, İstanbul, 2011.

Bağcı, S., Çağman, F, Renda, G. ve Tanındı, Z., Osmanlı Resim Sanat, Ankara, T.C.. Kültür ve Turizm Bakanlığı Yayınları, 2012, s.262.

Bedri Rahmi Eyüboğlu 1913 - 1975, Milliyet Sanat Dergisi, Sayı: 151, İstanbul, 26 Eylül 1975.

Berk, N., Hoca Ali Rıza, Ankara, T.i.B., 1986, s.26, 27.

Boran, M., Türk Minyatür Sanatinda Renk (Yüksek Lisans Tezi), Van, Yüzüncü Yıl Üniversitesi / Sosyal Bilimler Enstitüsü / Güzel Sanatlar Eğitimi Anabilim Dalı/Resim - İş Eğitimi Bilim Dalı, 2000, s. V.

Çoker, A. , “Avni Lifij'in Sanatı”, Avni Lifij Poşadlar, İstanbul, Aksoy Grafik, 1984, s. XXVII.

Çoker, A. ve İskender, K., "Cumhuriyet Dönemi-Resim”, Eczacıbaşı Sanat Ansiklopedisi. İstanbul, Yapı-Endüstri Merkezi Yayınları, 1997, s. 370, 371, 373.

Dal, E., “D Grubu”, Eczacıbaşı Sanat Ansiklopedisi, İstanbul, Yapı-Endüstri Merkezi Yayınları, 1997, s. 416, 417.

Dal, E. "Eyuboğlu, Bedri Rahmi", Eczacıbaşı Sanat Ansiklopedisi, İstanbul, Yapı-Endüstri Merkezi Yayınları, 1997, s.573.

Duben, İ., Türk Resmi ve Eleştirisi, İstanbul, Bilgi Üniversitesi Yayınları, 2007, s. 29, 74, 77, 86, 87, 88, 92, 94, 95, 142, 147, 148, 150, 153, 154.

Durmuş, M., "Bedri Rahmi Eyuboğlu 'nun Şiirlerinde Işık ve Renk Unsuru”, Türkoloji Dergisi, C.14, S.1, Ankara Üniversitesi Dil ve Tarih-Coğrafya Fakültesi, 2001, s.239-254.

Elibal, G., Aliye Berger Sergi Kataloğu, Devlet Güzel Sanatlar Akademisi, İstanbul, 1975,s.18.

Epikman, R, Osman Hamdi, MEB. İstanbul, 1967, s. 3.

Elden, E., Osman Hamdi Bey Sözlüğü, Ankara, T.C. Kültür ve Turizm Bakanlığı Yayınları, 2010, s. 24.

Erbil, D., Bedri Rahmi Eyüboğlu Sempozyumu, İstanbul, MSGSÜ, 2011.

Erol, T., Nazmi Ziya, İstanbul, Yapı Kredi Kültür Yayınları, 1995, s. 234.

Eyuboğlu, B. R., “Merhaba Renk”, Delifişek (Sanat Yazıları), Ankara, Bilgi Yayınevi, 1975, s. 155-157.

Bedri Rahmi Eyüboğlu Yaşasın Renk (Katalog), İstanbul, ̧̧̧̇ Bankası Kültür Yayınları, 2008.

Germaner, S. 18. Yüzyıl Avrupa Resmi, İstanbul, Kabalcı, 1996.

Giray, K., Ferruh Başağa. İstanbul, MAS Matbaacılık A.Ş., 2003.

Gören, A. K. , Avni Lifij, İstanbul, Yapı Kredi Yayınları, 2001, s. 320.

Şahin, E., “1914 Kuşağı”, Eczacıbaşı Sanat Ansiklopedisi, İstanbul, Yapı-Endüstri Merkezi Yayınları, 1997, s. 245. Şerifoğlu, Ö. F., Hoca Ali Rıza 1858-1930, İstanbul, Yapı Kredi Yayınları, 2005, s.56.

İpşiroğlu, N., Görsel Sanatlarda Alımlama ve Sanatlararası Etkileşim, İstanbul, Hayalperest Yayınevi, 2013, s. 170, 173.

Kınaytürk, H., Nurullah Berk, Türk Ressamları: 4., İstanbul, Garanti Bankası Yayınları. 1996.

Müftüoğlu, M. O., "Renk Üzerine Söyleşi”, İstanbul, MSGSÜ, 2016.

Müftüoğlu, M. O., Türk Resim Sanatında Desen'in Iş̧levi (Sanatta Yeterlik Eser Metni),

İstanbul, Mimar Sinan Güzel Sanatlar Üniversitesi / Sosyal Bilimler Enstitüsü / Resim Anasanat Dalı, 2005, s. 75.

Nesin, A., Aliye Berger Sergi Kataloğu, i̇stanbul, Devlet Güzel Sanatlar Akademisi, 1975, s.10.

Ocvirck, Stinson, Wigg, Bone, Cayton, Sanatın Temelleri Teori ve Uygulama, Çev. N. Balkır Kuru, İzmir, Karakalem Kitabevi Yayınları, 2015, s. 10.

Öndin, N., Gelenekten Moderne Türk Resmi Estetiği 1850-1950, İstanbul, İnsancıl Yayınları, 2011, s. 59, 70, 87, 104.

Özsezgin, K., İbrahim Çallı, İstanbul, Yapı Kredi Yayınları, 1993, s.138. Kırmızı ve Sanat, P Dünya Sanatı Dergisi, Sayı: 50. İstanbul, Raffi Portakal Antikacılık Müzayede, 2008, s. 62.

Renda, G., Erol, T. ve Berk, N., Başlangııından Bugüne Çağdaş Türk Resim Sanatı Tarihi, İstanbul, Tiglat Yayınevi, 1981.

Rona Z., Namık Ismail, Yapı Kredi Yayınları, İstanbul, 1992, s. 117. 